\title{
【Assigned project】
}

\section{REILLY'S PHENOMENON IN THE FIELD OF OTOLARYNGOLOGY}

\author{
By \\ YASUNOBU SUZUKI \\ Prof. of Oto-Rhino-Laryngology Keio Univ. School of Medicine
}

The author's interest in the Reillys phenomenon, which appeared unrelated to Otolaryngology, began with the study of primary shock. During the investigation of this subject I discovered numerous otolaryngeal symptoms related to this phenomenon.

In this paper I tried to bring up some of the facts which would give you the idea how the Reilly's phenomenon concerned us otolaryngologists.

The study of shock became the subject of our research as a result of sad experiences of surgical shock during minor otolaryngeal surgeries. After the war, within a relatively short period of time, I experienced a few cases of death due to surgical shock. Since I had not had a single case of death due to surgical shock in my previous twenty years of practice, those were my eye-opening experiences.

A healthy boy came to our clinic with his mother for tonsillectomy, and only a few minutes after the injection of local anesthetics the boy developed convulsion and died on the operating table.

Undoubtedly this sort of experience is a psychological shock to any surgeon as well as to the parents.

Therefore, investigation of the etiology and the treatment of surgical shock became my primary concern.

\section{Review of Surgical Shock}

In order accumulate the data concerning the surgical shock, letters of inquiry were sent to various otolaryngology clinics in Japan. Out of 235 inquiries, 58 were answered. These were 94 shock cases including 40 cases of death. They were clas. sified into five types according to the main clinical features. The types were; convulsion type, rapid syncope type, pale syncope type, respiratory syncope type and extremity numbness type.

The following table shows the number of cases of each type.

\begin{tabular}{lrrr} 
1. Convulsion Type & 49 & (death) & 34 \\
2. Rapid syncope Type & 1 & 1 \\
3. Pale syncope Type & 20 & 2 \\
4. Respiratory syncope & 6 & 3 \\
$\begin{array}{l}\text { Type } \\
\text { Extremity numbness }\end{array}$ & 18 & 0 \\
\hline & 94 & 40
\end{tabular}

This table indicates that in the clinical manifestation of primary shock, neural and vascular elements are predominant. Humoral factors such as an allergic or anaphylactic reaction are also important factors. But in many instances, in the very early phase of shock, a neural factor particu. larly autonomic nerve plays the major role. In other words, among numerous factors in the formation of surgical shock, autonomic nerve is likely to be the first system to react against the causative stimulation.

Thus we focused our attention to the relationship between the shock and the autonomic nervous system

\section{Experimental Studies}

Using guinea pigs, shock was induced by injecting irritants into the palatal tissues. Then the method of blocking the shock was investigated.

We chose guinea pigs in many of our experiments, because Reilly had recommended guinea pigs in this kind of experiment. When a certain amount of croton oil was injected into the palate of guinea pigs, $35 \%$ of them died from shock. 
Histological findings of lung, liver, kidneys and adrenals of these animals showed the changes described as "syndrome d'irritation" by Reilly. Changes in the microcirculation were studied using the mesenterium of rats. After the injection of croton oil, or electric stimulation of the palate, capillaries of the mesenterium showed vasoconstriction followed by vasodilatation, stagnation and stasis. In some instances capillary back flow was observed. If those changes were the result of autonomic nervous system irritation, chlorpromazine may be effective as a blocking agent. Animals were treated with chlorpromazine prior the same experiment. This time no shock reaction occured. Chlorpromazinetreated animals did not show any change in the visceral organs, nor in their capillary circulation.

Injection of adrenalin of certain amount, instead of croton oil, induced shock, which was also arrested by chlorpromazine.

\section{Anatomical Consideration.}

When a stimulation is applied to the peripheral autonomic nerves of the palate, two kinds of route are considered through which the impulse reaches the effector organ. One is a direct descending route by way of local autonomic ganglia, and the other is the ascending route to the autonomic nerve center in the midbrain from which impulses are discharged into the bilateral descending autonomic nerves. We have successfully demonstrated both of these pathways by histological examination of autonomic ganglia using an electron microscope, and by electroencephalographic tracing of central autonomic nervous system during the shock.

Histological investigation of autonomic nerve fibres in the pharynx and the nasal cavity of men and animals revealed that autonomic nerve fibres are most abundant in the tonsillar region followed by the palate and the nasal cavity.

Those observations give some explanations on the etiology of the surgical shock durirg tonsillectomy.

\section{Character of the Irritants}

We have found that the peripheral autonomic nerve is stimulated by mechanical irritation as well as with drugs or toxic substances. Injection of iodized oil or normal saline around the tonsils or in to the tonsillar cysts in men, caused changes in the electrocardiogram and in the urine.

Injection of non-absorbant materials such as talc or silicon into the palatal tissue of experimental animals induced changes in the visceral organ, mainly vascular in nature, as described by Reilly. Likewise bacterial toxins will affect the host as irritants to the autonomic nerve fibres. Bacterial toxins prepared from streptococci, diphtheria bacili, and staphylococci act as strong irritants to the peripheral autonomic nerves.

For a severe case of diphtheria, administration of chlorpromazine in combination with antiserum and antibiotics is the treatment of choice, the rational being chlorpromazine will reduce the reaction against the bacterial toxin and help to prevent the exhaution of the patient.

\section{Clinical Investigation}

Electrocardiogram and renal function tests were given to patients before and after the tonsillectomy. Nearly $70 \%$ of patients showed slight changes in ECG during the surgery, particularly after the injection of local anesthetics. The ECG changes consist of depressed S-T segment, flattened $T$ wave, altered $\mathrm{P}$ wave and prolonged Q-T time. These changes are very slight and interpreted as variations within normal limits. These are indicative of minor and reversible myocardial disturbances within the subendocardial layer. In an hour after the surgery, patients with ECG changes are reduced to $50 \%$, and on the seventh postoperative day, $30 \%$ retained the altered ECG.

Renal function studies on the same patients showed slight increase of glomerular filtration rate (GFR), while renal plasma flow (RPF) was unchanged. These findings were interpreted as an elevated glomerular filtration pressure due to vasoconstriction of the efferent glomerular arteries. This type of change is known to occur after autonomic nerve stimulation of the kidney. 
Some patients showed transitory proteinuria and hematuria of less than a week duration. In those patients, $\mathrm{C}$-reactive protein became positive in the immediate postoperative period and gradually turned to negative. ASLO and ASTA variations after the tonsillectomy were inconclusive. These findings indicate the close relationship between Reilly's phenomenon and the tonsillar focal infection.

\section{Other Experimental Studies}

The effect of palatine stimulation in guinea pigs upon the inner ear was investigated by amino acid analysis of the perilymph. After the irritation, we demonstrated four abnormal amino acids in addition to seven amino acids of normal perilymph. They are; cystine, histidine, arginine and lysine. The appearance of these abnormal amino acid was not inhibited by chlorpromazine, but suc- cessfully blocked by C.6 (Hexamethonium Bromide).

In the experiments we have reported, the site of stimulation was mainly the pharynx. However, there is a report that an irritation applied on the infraorbital nerve induced changes in the visceral organ similar to those observed in our experiments. In another experimental study, the irritation of one bronchus produced certain changes in the contralateral lung.

\section{Conclusion}

Our investigation of the Reilly's phenomenon in the field of otolaryngology is still far from complete. However, the result of our study reveals some interesting facts which lean to a better understanding and a management of numerous clinical problems in otolaryngology.

\title{
耳鼻咽喉科領域におけるレーリー氏現象
}

\author{
度義大学医学部教授
}

$$
\text { 鈴李李安恒 }
$$

\section{はじめに}

私をレーリ一氏現象といら，比較的耳帠咽搌科とは関 係のなさそうな問題と取りくむのを余儀なくさせたの は，手術時に 発生するショックといら問題からであっ た.

しかし，その後この見象はショックといら問題を離 れて，耳囱咽喉科の領域にとつて，非常に重要な問題を 含むことが分り，種々の疾患や症状と密接な関係を有す ることが解明されることになつたのである。

後述の如く，レーリ一氏現象之は，身体のある個所以 加えられた過剩刺激が，這隔の䑏器や器官に及ぼす病变 であるために，閣題は複雑多伖に亘るといわねね゙ならな い.

扱，この研究の端緒となつた、ショックという問題で あるが，これは今日迄，慗だしい多数の動物を㬢性に
し，且又，人間について広汎な研究がなされているに拘 らず，今何，未解決の点を数多く残している.

私達の領域て経験するショックは，大部分が手術や処 置に連なる一次性ショックであるが，この生体全体が関 与する抑制状態，そして循環不全を萑き起す深刻な現象 は，直らに生死の境を彷うものであるから，非常に重大 な事態であると考えねばならない。

\section{一次性ショックの原因}

私達は，まず手術時に和けるショックの原因を追求 し，更にショック並びにショック死の予防ができぬかと

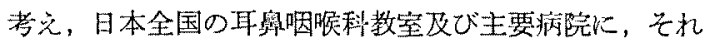
に就いてのアンケートを求めた処 ${ }^{29)}$, 総数 235 の内, 580教室並びに病院から返事を得ることができた，てこ でこれを私達なりに，分類を行つてみると結果は表!の 如くになつた。 
表 1

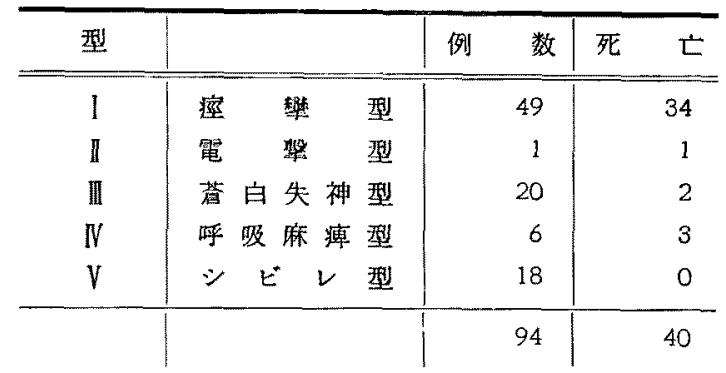

このよらにして見ると、ショックの型には神経，血管 系の要素がかなり大きな要素を占めているように思われ 万.

舁際ショックの時には，体液の上にb恋化が起ること が明らかになつてきているし，アレルギー，アナフイ キシー25) の関保む考えられるが，いられにしてもその 亟々初期以動くのは神経系特に自律神経系と考光てよい ようである、そこで，この際における自律神経系の動き に就いて研究を始めたのであるが，ショックという動的 変化を一つの函数之侾える時，この函数の勩きは非常に 多くの誌数によつて定まるもので，自律神程系の動的变 化はその内の一のの变数にしか過ぎない，

従つて私澾が取扱つた研究は自律神経の動的变化と云 ら一変数の偏微分に他ならない。

併しこの変数はショックの時の多くの变数の中で時間 的に最も初めに勤くことの多い変数で，これ以外の变数 はこの变数が動いてから，それにつれて動くょらに考え られる。

斯かる考えの下に，先づれれツトを害駼動物として この口蓋に過剩刺激を加壳，ショックを起させ，それに 成功したらこれを予防し得るか不かといら試みを行つ $ホ^{5) 6)}$.

刺激物質としては表 2 の如く，オリーブ油，アドレナ リン加 $0.5 \%$ プロカイン，木蛢十ヒマン油，タルク．1 \%鍇酸鉛液，シリコン、クロトン油原液，クロトン，才 リーブ混合液，交流電気などを試みたが，その結果，ク ロトン油原液を用いたものでは20 例中 10 例がショック 症状を是して死亡したので，私達の研究目的に最も適し たものとしてこれを採羽した。

クロトン油は巴豆の種子から採取した植物油であり， 局所刺激性が極めて强い桨物である。この刺激物質とし てのクロトン油を臽々の量にして，モルモットのロ蓋に 注射してみると表了に示寸如く，0.05cc では17\%，0.1
表 2 口蓋に与えた刺㛾物の種類

\begin{tabular}{|c|c|c|c|c|}
\hline & 刺 & 物 & & 例数 \\
\hline オ & - & 油 & 0.1 & 2 \\
\hline \multicolumn{3}{|c|}{ アドレナリン加 $0.5 \%$ プロカイン } & $0.1 \sim 0.5$ & 5 \\
\hline \multirow{2}{*}{$\begin{array}{l}\text { 水 } \\
\text { 夕 }\end{array}$} & ウ + 七 & $\checkmark$ シ 油 & 約 0.2 & 2 \\
\hline & ル & $\eta$ & $0.1 \sim 0.2$ & 12 \\
\hline 1 & 醀 & 敛 & 0.1 & 6 \\
\hline 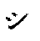 & $=$ & 油 & $0.1 \sim 0.5$ & 10 \\
\hline$\eta$ & 口 12 & 油原 液 & $0.05 \sim 0.3$ & 20 \\
\hline 400 & 䪪クロトンク & リーブ油 & 0.1 & 5 \\
\hline 交 & 流 & 気 & $38 \mathrm{~V} 1$ 分 & 1 \\
\hline & 諳十 & & - & 63 \\
\hline
\end{tabular}

表 3 クロトン油原液口菬进射

\begin{tabular}{c|r|r|r}
\hline 使用 量 & 生存例数 & 死亡例数 & 計 \\
\hline \hline $0.05 \mathrm{cc}$ & 5 & 1 & 6 \\
$0.1 \mathrm{cc}$ & 4 & 2 & 6 \\
$0.2 \mathrm{cc}$ & 1 & 5 & 6 \\
$0.3 \mathrm{cc}$ & 0 & 2 & 2 \\
\hline 計 & 10 & 10 & 20
\end{tabular}

表 4 クロトン油腹部皮下注射

\begin{tabular}{c|r|r|r}
\hline 使 用 量 & 生存 例数 & 死亡例数 & \multicolumn{2}{|c}{ 計 } \\
\hline $0.05 \mathrm{cc}$ & 4 & 0 & 4 \\
$0.1 \mathrm{cc}$ & 15 & 0 & 15 \\
$0.2 \mathrm{cc}$ & 1 & 4 & 5
\end{tabular}

cc では 33\%，0.2cc では 83\%，0.3cc では100\%，ショ ツク死を起すことを知つた。

其処でこれと同じ量のクロトン油をモルモツトの腹部 度下に注射したところ，表 4 の如く $0.05 \mathrm{cc}$ と $0.1 \mathrm{cc}$ を 注射したものでは1例もショックを起さなかつた。

これを图示（図1）すると，クロトン油を口蓋に注射 するといらことは，皮下に注射する事とは違つた意義を 有し，口蓋はこの注射に対し特異性を有していることが 箱われる。そしてこれは後に行つた阻止面験を考え併せ てみて，0.1ccがこの実験に最も適した量と考えられた。

そこで更にクロトン油の口蓋注射と腹部注射との比較 をクロトン油 $0.1 \mathrm{cc}$ について例数を增して繰り返した 処，同様な数值が得られたので，口盖という部位が過剩 刺激に対して 特異性を有するといら確信を持つたのて 
图 1

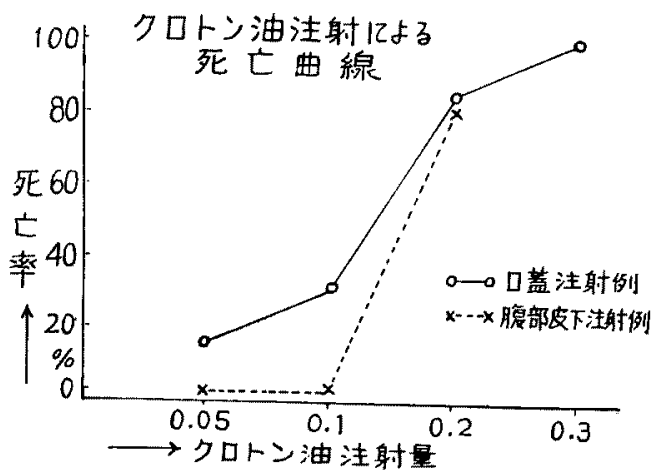

ある。

次炕クロトン油因るショック発生を阻止するため， 予めクロールプロマジンを投与してみた。 その方法は 表 5 に示すよらに 3 時間前から総量，体重 $1 \mathrm{~kg}$ に就き $1 \mathrm{mg}$ を3分割して注射した。 この結果, ショックを起 したものは 1 例る認められなかつた。

併し口蓋注射と同時にクロールプロマジンを用いた 20 例では 14 例がショック死を起し，使用しないものと の間に有意の差を認め得なかつた。

表 5 クロールプロマシンンとよる阻止実験

\begin{tabular}{l|r|r|l}
\hline & 投与時間 & 量 $\mathrm{cc}$ & \\
\hline \hline \multirow{3}{*}{ 前 } & 3 & 0.5 & クロールプロマジン \\
& 2 & 1.0 & $1 \mathrm{mg} / \mathrm{kg} \mathrm{R}$ に相当 \\
& 1 & 1.5 & \\
\hline
\end{tabular}

\begin{tabular}{l|r|r|ll}
\hline \multicolumn{5}{c}{ クロトン油 $0.1 \mathrm{cc}$ 口蓋注射 } \\
\hline 後 & 1 & 1.5 & 同 & 上 \\
& 2 & 1.5 & &
\end{tabular}

この静から，動物実験ではクロールブロマジンはショ ックの予防には有効であるが治療効果はない上うに思わ れた．併し私達が实際，臨床上ショックの時に用いた場 合には有効の上うに思われる。この上うな例に就いては 既に雑誌「耳奥咽喉科」に発表してあるので，その第 30 巻第 10 号 8) 学参照されたい。

侣, 当教室過去 10 年間に括けるショック発生及び 死亡例数は表 6 に示寸如く, この研究に着手する以前に は，手術時，ショック死に遭遇する事が多々あつたが， この研究を始めてから、最近ではショックを起した例は あるが，死亡した例は全くなくなつた。 これはショック と云うるの全体に対する対策が建てられた事にも由る
表 6 わたくしたちの救宝におけるショック 発生㧤上び死亡数

\begin{tabular}{|c|c|c|c|c|c|c|}
\hline 年 & 発 & 生 & 件 数 & 死 & 亡 & 数 \\
\hline 昭和 28 年 & & & 3 & & 3 & \\
\hline 29 & & & 3 & & 3 & \\
\hline 30 & & & 2 & & 1 & \\
\hline 31 & & & 1 & & 1 & \\
\hline 32 & & & 4 & & 0 & \\
\hline 33 & & & 4 & & 0 & \\
\hline 34 & & & 3 & & 0 & \\
\hline 35 & & & 2 & & 0 & \\
\hline 36 & & & 0 & & 0 & \\
\hline 37 & & & 0 & & 0 & \\
\hline 詰 & & & 22 例 & & & \\
\hline
\end{tabular}

が，私達の研究も一役買つているものと思う。

\section{病理絸織学的所見}

扱，クロトン油を口蓋に注射してショックを起した時 の諸臓器に和ける病理組織学的所見は, 主として血管系 に郝ける変化で，充血，警血，浮腫及び出血で高度の場 合には变性が認められる。

これに対して，予めクロールプロマジンを用いたもの では全く変化をみとめなからた。

これを図で示すと，図2はクロト油のみで，図3はク ロールプロマジンを予め投与してからクロトン油を注射 したときの肺である。次は肝で四 4 はクロトン油のみ， 図 5 はクロールプロマジンによる阻止例である. 図6は 撉のそれでクロトン油のみの場合，図7の阻止例との間 には明らか汇違いが認められる。最後は副腎で図 8,9 の 如く，兩者の間には明らかな差が認められる。

以上の所見はフランスの臨床病理学者 J. Reilly12 2)3) が発見した Syndrome dirritation 即ち過剩刺激症候群 に見られる祸理組織学的所見に一數するものである。

\section{レーリー氏現象}

レーリーは1925 年, チフス遈の臨床と病理の研究中 に，パラチフス B菌を動物の晹間膜リンパ節内に植省， 人のチフス症の時に見られるょうな臨床莚状や腸の $\mathrm{Pa}$ yer 氏板の潰瘍が起るのを認めた，従来動物のチフス症 についての研究では，循環血中に直接菌を注射しても， この疾患の発症がなされなかつたものである。この变化 は更に菌量を僅かにしても起るし，極めて薄く稀釈した 菌体内毒素でも起ることがその後の実験に上り明らかに された.このように菌体内毒素を，極く懄注射した 
図 2

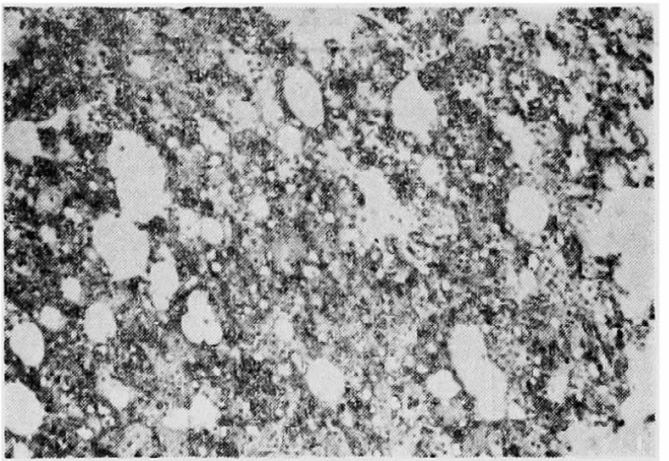

図 4

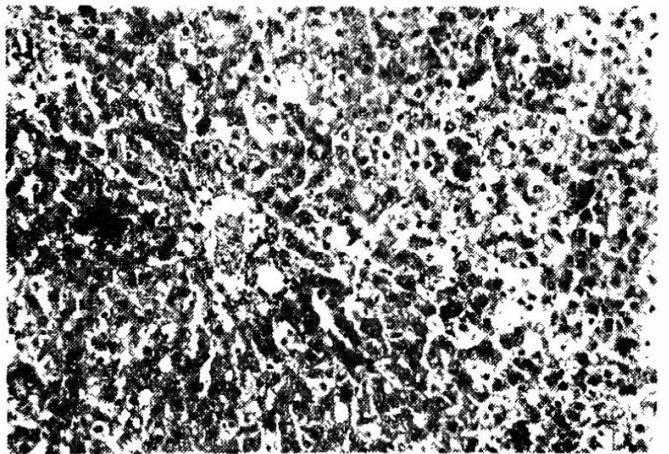

图 6

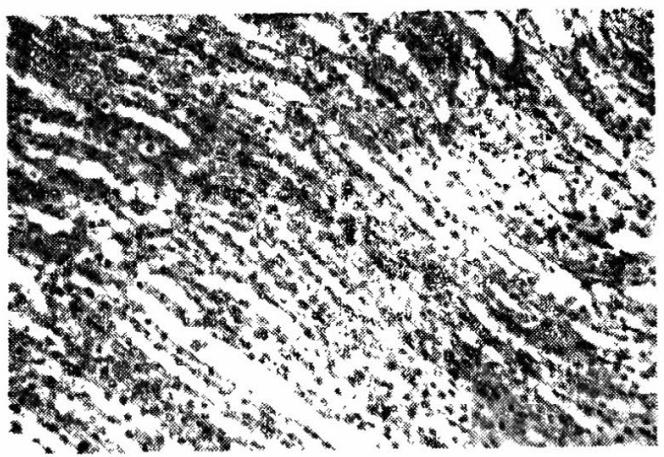

图 8

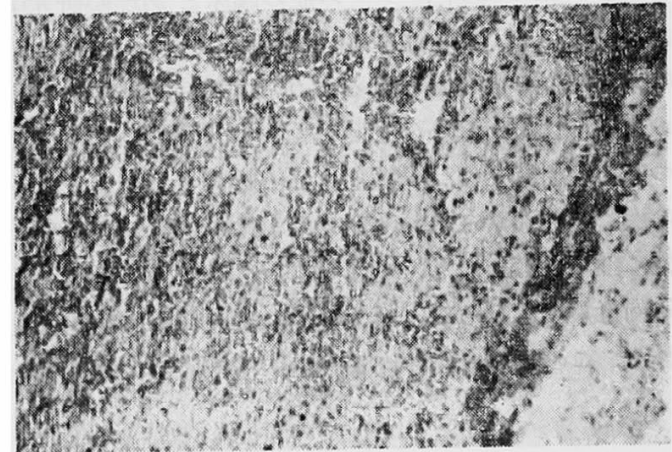

图 3

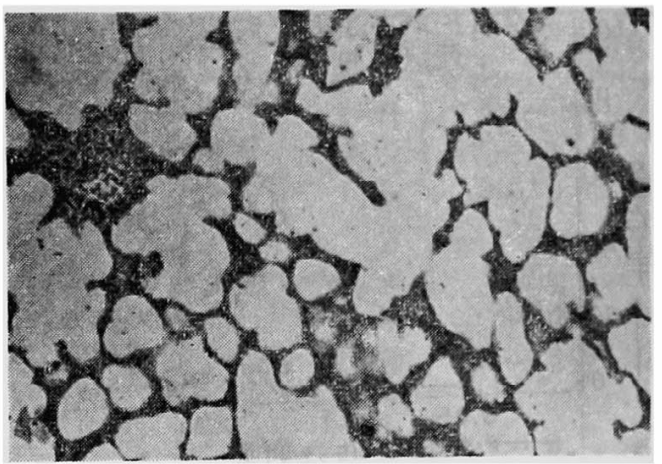

图 5

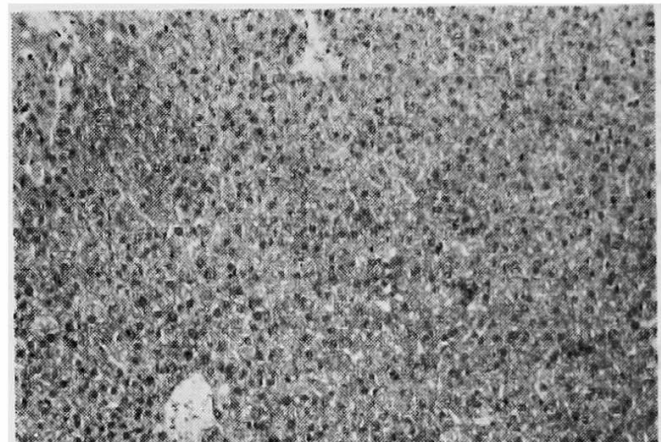

図 7

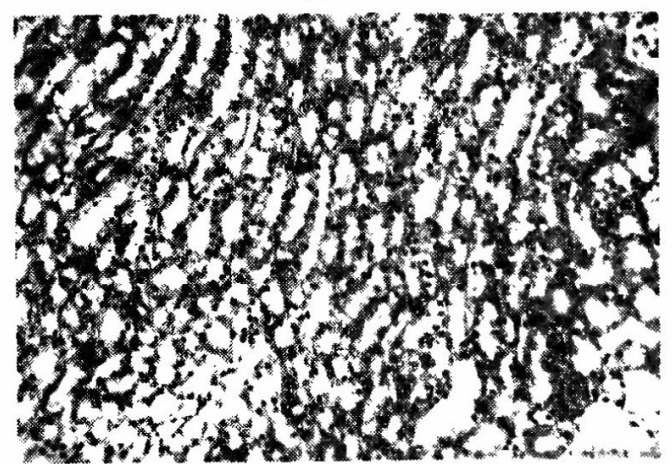

图 9

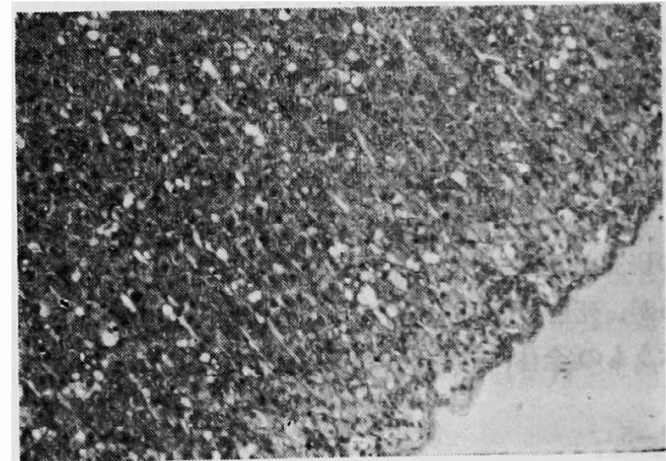


洔, 注射部位から離れた場所に壊死などの病变を起すと いう事は，いか以説明すべきであろうか。

この毒素が血流依つて搬ばれ，直接病変部作用す

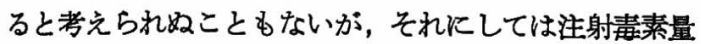
が非常に敬ないようと思われる。

Reilly はその原因を自律神経に求め, 同一稀釈菌体 内毒素を内臓神経に直接接触させ，前に述べた実験之同 様な腸管の病変を認めた. これに依り毒素の作用は自律 神経を伝つて遠く伝達され，その部に变化を起すことが 解明されたのである.この現象が後に過剩刺激症候群又 はレーリー氏現象と称えられるに至つたるのである. 又 その後, 過鄱刺激の部位を常に自律神経に求め乍ら, 先 に行つたチフス菌体内畾素の代りに物理刺激，例党ば 外傷とか感応電流を用いたり，化学刺激として腐蝕性物 質のよらな物質を用い神経刺激を行つて見た．その結果 はチフス菌体内諳素に因り生じたと全く同様な腸管障害 を認め, 顕微鏡下に和ける变化も, 刺激物質は異っても チフス菌体内毒素を使用した時と全く同一変化である事. を発見したのである．

これ等の事からこの変化はチフス菌だけに依つて特異 的に起る変化ではなく, 所謂, 非特異的な性格を有する ものであると云う事が解明された。

即ちレーリー氏現象とは神経, 特に自律神経の過剩刺 激による遠隔藏器や組織に蛙ける血管系を主体とする非 特異的反応であるが, その刺激となる物質は細菌, 細菌 毒素はこれより，一般の物理化学的のいかなる刺激でも 差支えない，又刺激をらける部位は腹部でも胸部でも頸 部でも，皮膚粘膜であろらと，そこが自律神経装置を豊 富に有する部位であれば何処でもよい，そしてこの刺激 によりこの部に存在する自律神経を介して自律神経の発 達した遠隔の心，腎等の臓器に血管系の反応を呈するも

図 11 (1) ヘマトキシリンエオシン染色に よる鬼の扁桃

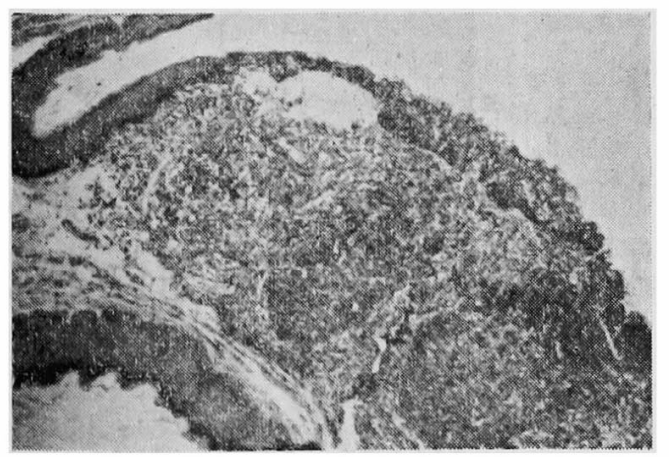

のである.

\section{私達の実験成績とレーリー氏現象}

そこで, 前述の私達の実験成績を振返つてみると， ク ロトン油をモルモットの口蓋に注射した時の内蔵諸臓器 の変化は、レーリーが自律神経を種々の物質で刺激した 時に起る非特異性変化と全く一致するものであつた.

この内蔵器の变化は口蓋と云う部に存在する知覚及び 自律神経を刺激して，両者のらち主として自律神経を介 して起つた病変, 即ちレーリ一氏現象之解釈してよいむ のと思う. 又更に, この変化はクロトン油の代りに電気 刺激あるいはタルクやシリュンのような体内に吸収され 難い粒子の粗い物質を注射しても全く同じ变化が起る ことを知つたので，非特異性の反応と云い得ると思わ

图 10 リンパ小節の周囲から芽中心に 向つて進入する植物神経線維

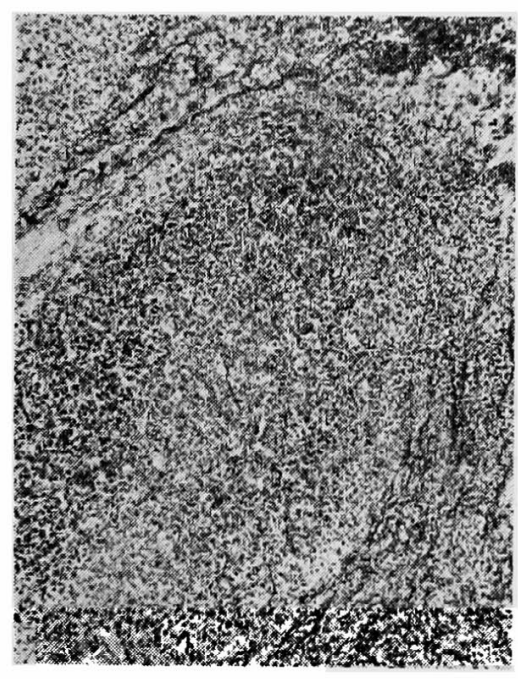

図 11 （II）鬼の扁恌の植物 神経終網

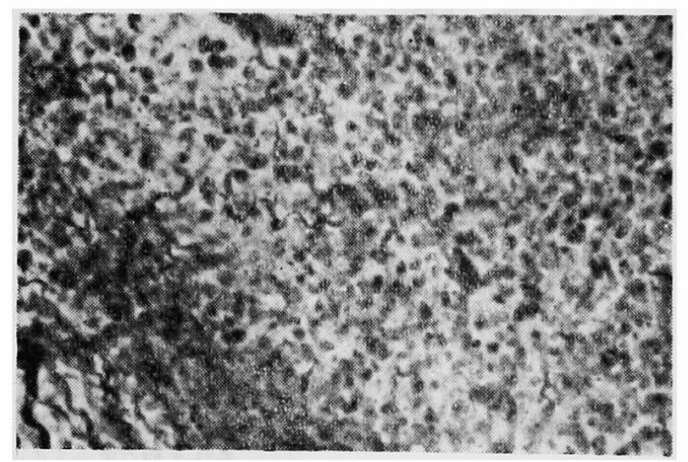


れる。

この刺激部位となつた口蓋や咽頭にお ける知覚並びに自律神経系の分布状態を 調べて見ると，図10，11 は人18) と鬼24) の扁桃の組織像であるが此処に見られる ように両者共, 神経殊に自律神経が豊か に分布している. 又これより稍々少ない と思われるが，人の口蓋 9) 10) や鼻腔 ${ }^{12)}$ の組織にも同様に良く発澾した自律神経 が明らか認められる. 其故, この事は 扁桃や頸部に加つた刺激が過剩刺激にな り易いと云う一つの裹付けになると考え られるし, 又実際臨床的に扁桃や頸部の 手術の時は身体の他の部位に找ける手術 に比べてショックが起り易いといら事に 関係があるように思われる. 又試みに薬 物や毒素で無いもの即ち生理食塩水やモ ルヨト゚ールを扁桃の周囲に注射すると， これに依り心電図や尿に変化 ${ }^{18)}$ が生ず る. 図 12 は仰臥位で 扁桃周囲にモルョ ドールを注射したもので，図13 は注射 部位の模型図である。図14 はとの際の 心電図で ST 下降，T 平低などが認め られる. 図15は扁桃チステにモルョドー ルを注射したときのX線写真であるが， この際には尿蛋白に変化があらわれる.

このように口蓋, あるいは扁桃という
区 $\quad 12$

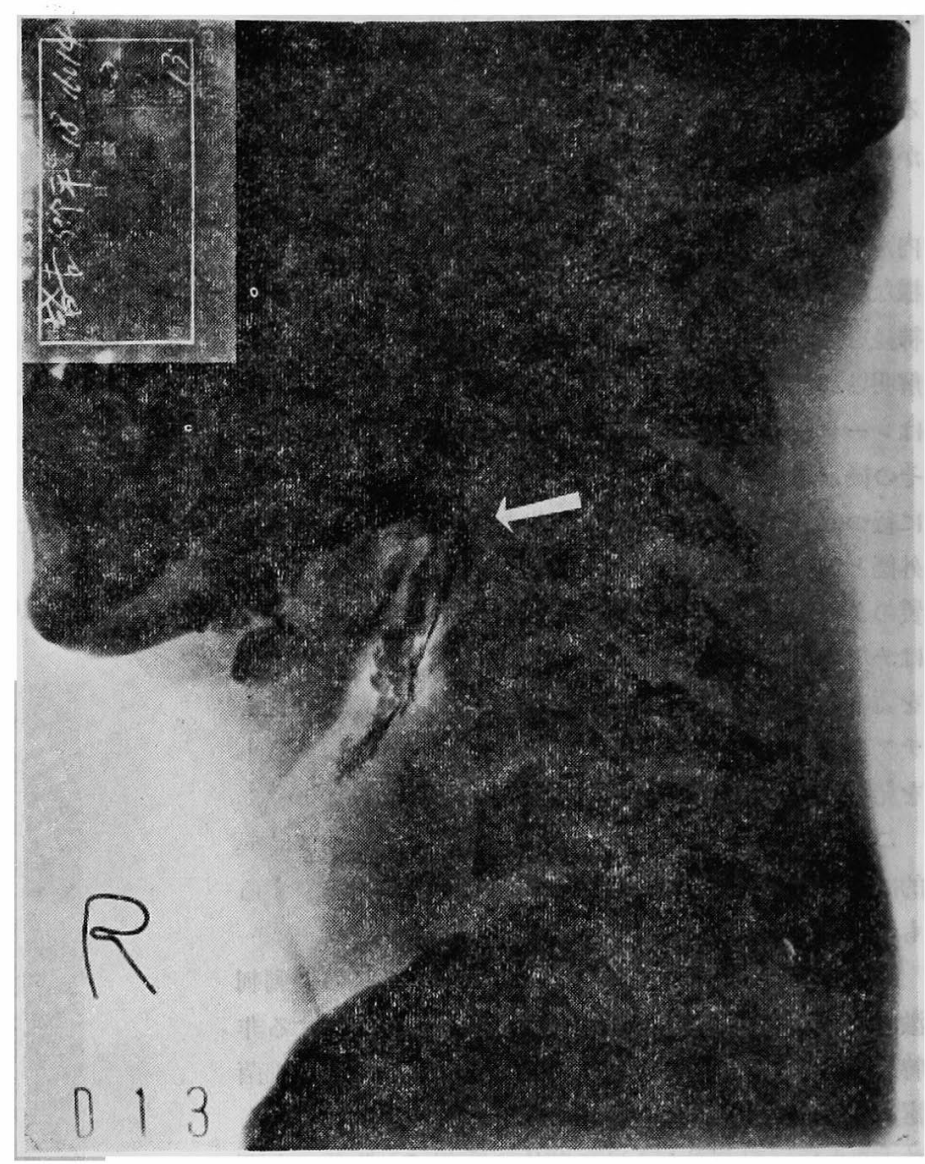

図 13

モルョドール注射部位模 型図

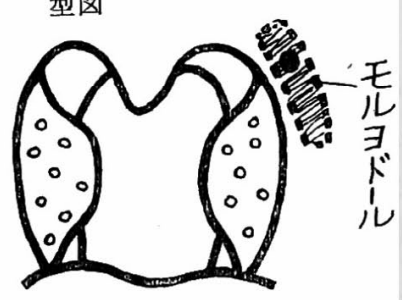

図 $14 \rightarrow$
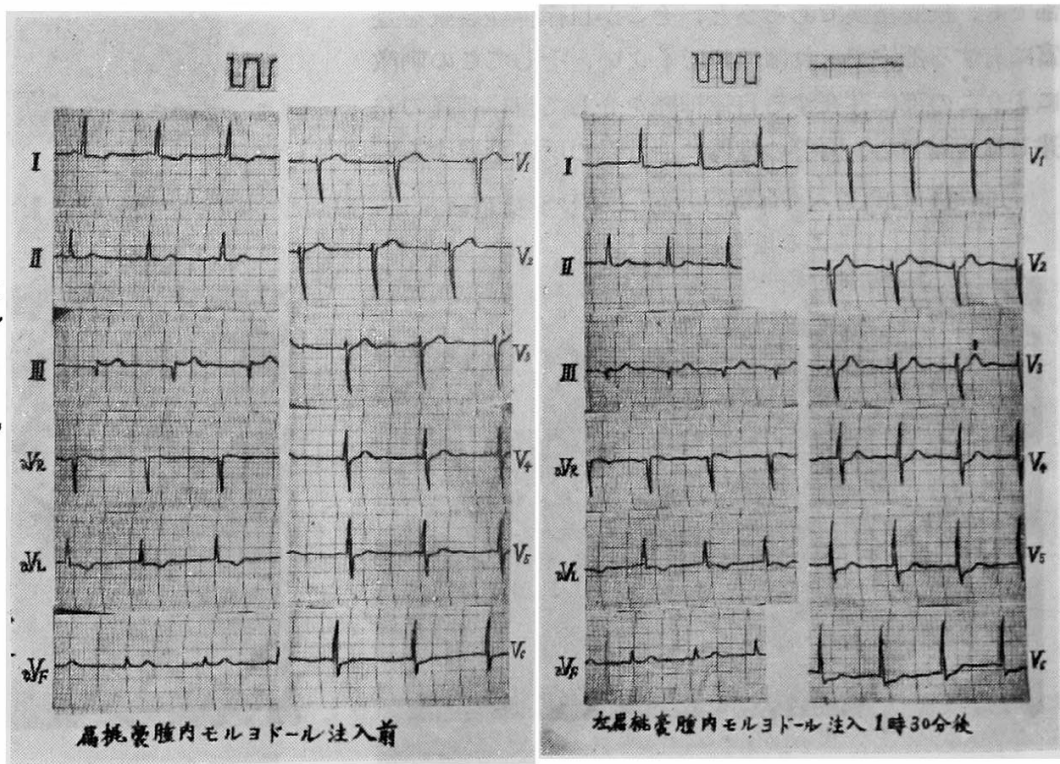
特殊な部位の刺激はヂフテリヤ堛素といら向神経性の物 質を使用することによつて更に激しい変化が生ずるであ ろう、私達はモルモットの口盖にジフテリヤ蕃素 26) を 注射してこれを検討した結果, 大腿皮下や静脈に注射し たものと比へて遙かに強い病変を起す事を発見した. 又 自律神経莘と云われるアドレナリン 27) を口蓋に注射し

\section{图 15}

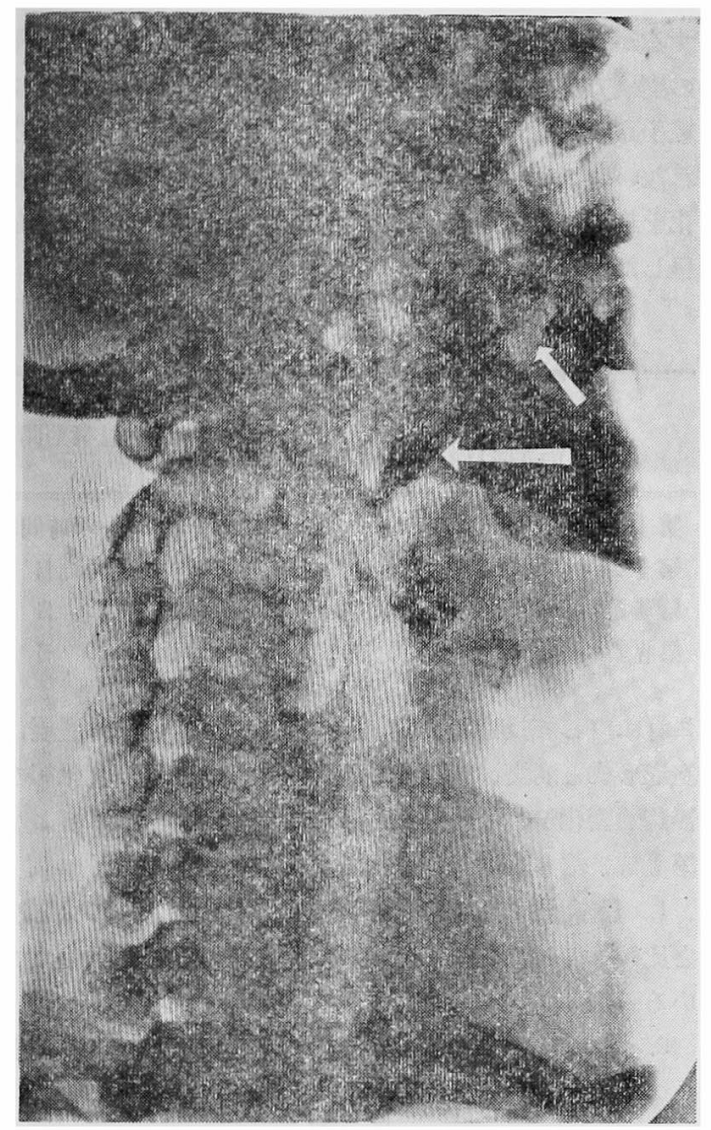

た際にも同様の変化が起るのが実験により明らかにされ た. 扨, 次にこのような口蓋偏桃に注射された物質が 神経を刺激してこのような变化を起すのではなく，吸収 されて循環血液中に移行し，諸蔵器に病変を起すのでは ないかと云う疑問を解明する意味と非特異的病変である 事を裹付けるため，次のような実験を行つた。これは Sac. Jugulaire (頸静脈覆法) $)^{\text {) }}$ という方法で，動物の 頸静脈を上下二ヶ所で㛜重に結紮し，できた懐の中に種 々の刺激物質を注入すると，それらの物質は㖩内に存在 したまま鼠壁の自律神経を刺激し，これにより遠隔の心
腎等に血管系の反応を起すのである，この方法により， 溶連菌の Whole culture, 培養㴓夜, あるいはワクチン をそれに使用したが, Whole culture, と培養渴液のと きには腎系球体に可逆性の变化が認められたが，その時 使用した起筒炎株と非起筒炎株との間には差を認めなか つた.

この実験は溶連菌性アンギーナによつて起る筒炎は咽 頭の自律神経の過剩刺激即ちレーリー氏現象によつて生 ずる事の可能性を示嘫するものであり，腎炎の発生機序 の一端を解明し得たものと思う。

双，それならばこの自律神経刺激はいかなる経路を通 つて伝達されるものであららか. 私達は餗の扁桃を刺激 して脳波に及ぼす影響を追求した。

実験に使用した電極は直経 $0.5 \mathrm{~mm}$ と $1.0 \mathrm{~mm}$ の螺旋 電極で, その刺入部位は, 前頭葉皮質に 2 本, 前視床下部 に2 本, 後視床下部に 2 本, 網様体に 1 本, 合計 7 力所 からの誘導を同時に行つた.

図 16 家鬼安业㭙脳波

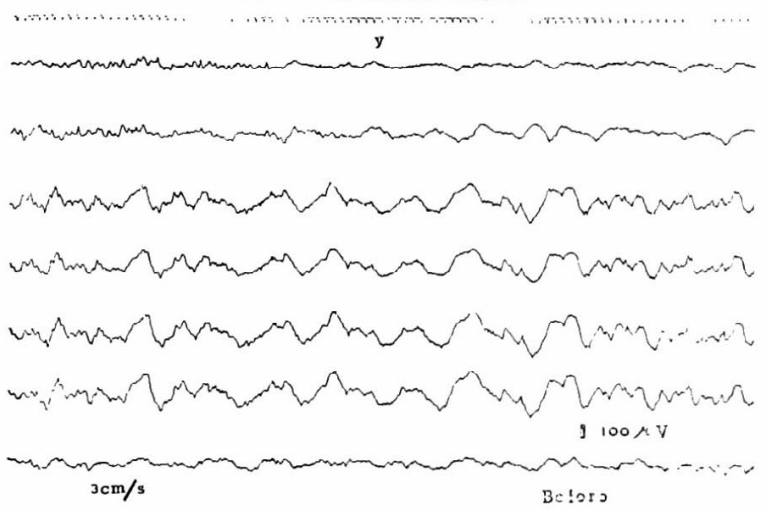

図 17 クロトン油注入後脳波
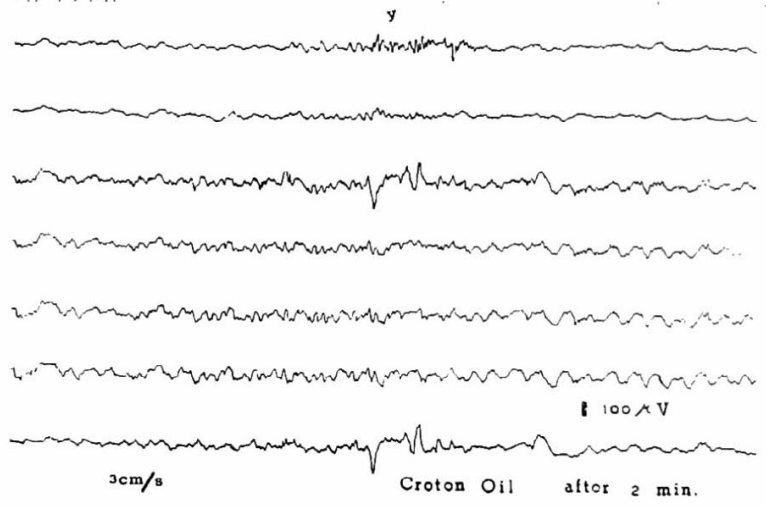
図16は刺激前安静時の脳波で図 17 はクロトン油扁桃 刺激後間もなくの脳波で, スパイクの出現と振動数の增 加と振幅の減少が極めて著明に認められた。

図 18 は予めクロールプロマジンを投与した際にみら れる安静時の脳波で図19 はその家雭の扁桃にクロトン 油刺激を加えたもので, 安静時の脳波との間に全了差が 認められない:こ絓の事から，家鬼の扁桃をクロトン 油で刺激すると，脳波に変動をみとめ，又予めクロール プロマジンを投与して拉くと，それが遮断されるものと 思われる. 更に又，両側の迷走神経を切断し中枢端を電 気的に刺激すると反対側の迷走神経の中枢端からインハ ルスをとることができる。これ等を考光合せてみると，

一側の扁兆刺激で中枢に達した與鹪は反刘側の自律神䋊 にも達し左右各臟器の病変を招来するものと考兄られ る.

図 18 クロールプロマジン投与後安青時脳波

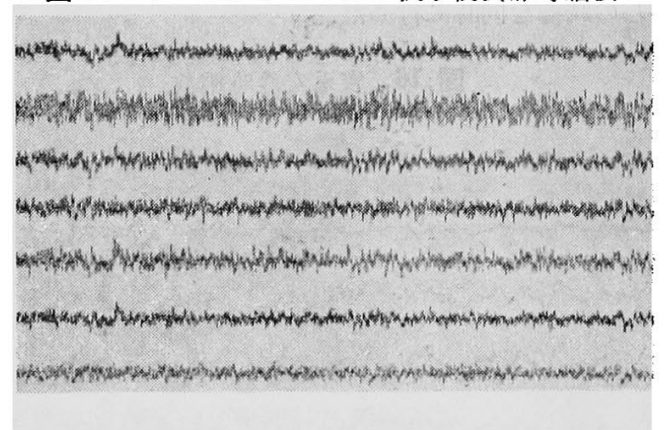

図 19 クロールプロマジン投与後クロトン油 这入後脳波

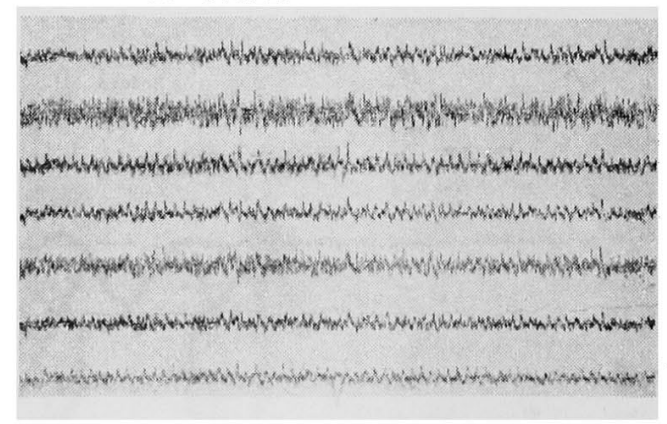

即ち過剩刺激により身体の雨側の臓器並に組織に変化 を生ずるのはこの理由からであらう，斯くの如く咽頭に 加光られた過剩刺激は全身臟器に介達され悪影響をる及ぼ すので, 臨床上症候的に激しい咽知頭ジフテリヤで中蕀 症状のある時や小児中耳炎で中唁症状を伴う場合には； 抗玨素血清やペニシリン，アイロタイシンなどの投与及
び鼓膜切開に加壳てクロールマ゚マシンを併用する事は 8) 29)，クロールプロマジンの有主る自律神経廘断作用に ょり環境煩応する事 4)，即ち生体が刺激飞抵抗し七無 闧にェネルギーを消耗する事が無い上うにといら配慮か らてである。

\section{口蓋過剩剌激時における上頸部交感神経節の变化}

次に自律神経が豊富に分布している口蓋粘膜に過剩刺 激を加えた場合，上頸部交感神経節にいかなる変化が生 ずるか, 光学並びに ${ }^{11)}$ 電子顕微鏡 ${ }^{14)}$ で追求した，そ の実験方法は表 7 の如くである. 第 1 群では光学並びに 電子顕微鏡所見共儿神経節細胞には殆んど变化が認めら れない。これは侵㽝が激しく急速であるため形態学的変 化を起す以前に過剩な防禦反応を生じ：ショック症状を 呈したものと考えられる.

表 7

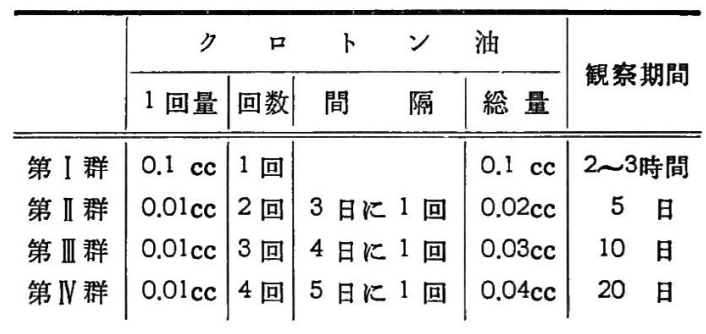

これに対して長時間慢性刺激群では神経節細胞の腯脹， 空泡形成と崩瀤, 萎縮, Nissle 顆粒及び核の変化等の 器質的变化が認められる. この変化の程度は第【群より 第凹群，第四群より第 $\mathrm{N}$ 群と順次汇高度となる.

1. 腫脹, 正常の神経節細胞(図 20 光顕, 図21, 電顕) と比較して細胞質は膨化し，やや蹯となり核も膨化して いる(図 22).

2. 空胞形成と崩襄, 空胞の大きさは種々で 1 数個 图 20

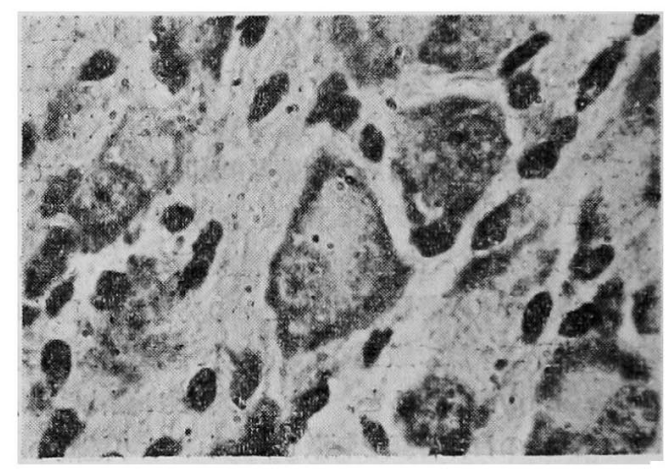


図 21

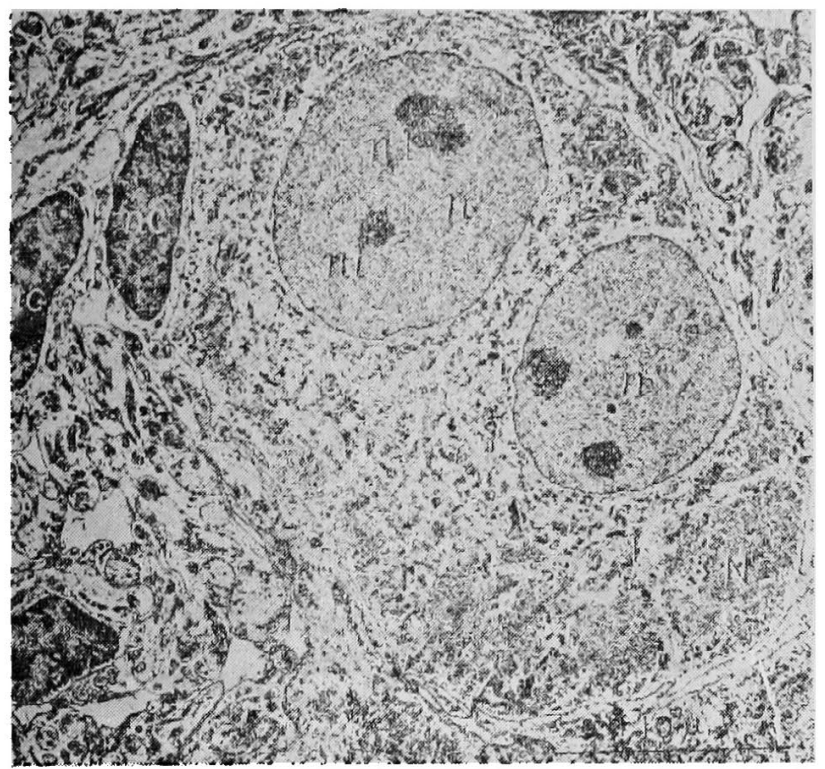

あり，細胞の周辺部，中心部に現われる，時 には多数の空胞によつて 細胞が充満され, 遂 には崩壊する（図 23, 光顕, 図 24, 電顕)

3. Nissle 顆粒の変化 正常神経節細胞では Nissle 顆粒は細胞周辺部に多く分布するが， 核周囲に迄認められることもある(図 25). 又, 長時間刺激群では始めに顆粒の配列が乱れ，一 部濃染してくる. 次いで Chromattolysis が主 として限局性及び中心性に起るのがみとめられ る(図 26).

電子顕微鏡像では，この部分に一致して，扁 平罢状の粗面小胞体が規則正しく(図 21，27）, あるいは，不規則に配列している．又これ等の 周辺部に 微細顆粒の 密集が認められる。一方 Chromatolysis は粗面小胞体の疎開々著明な減 少，消失として表現される(図 29). 特に核周 辺部に著るしいことは光学顕微鏡所見と一致し ている.

4. 菱縮 神経節細胞の萎縮が散在性に，あるいは某 性に認められ，細胞体は不正形で濃染し核も同様に変化 する(図 30)，対䀡群にも認められるが，実験群に比較 してその数は遥かに少ない

5. 核の変化 正常の場合（図 20,21）は円形，棈円 形であるが，前述のように細胞体の腫脹及び萎縮に伴い 変化する. 又不正形となり核膜に著しい凹凸がみられる (図 29). 核の偏位孔憱々認められる。

图 24

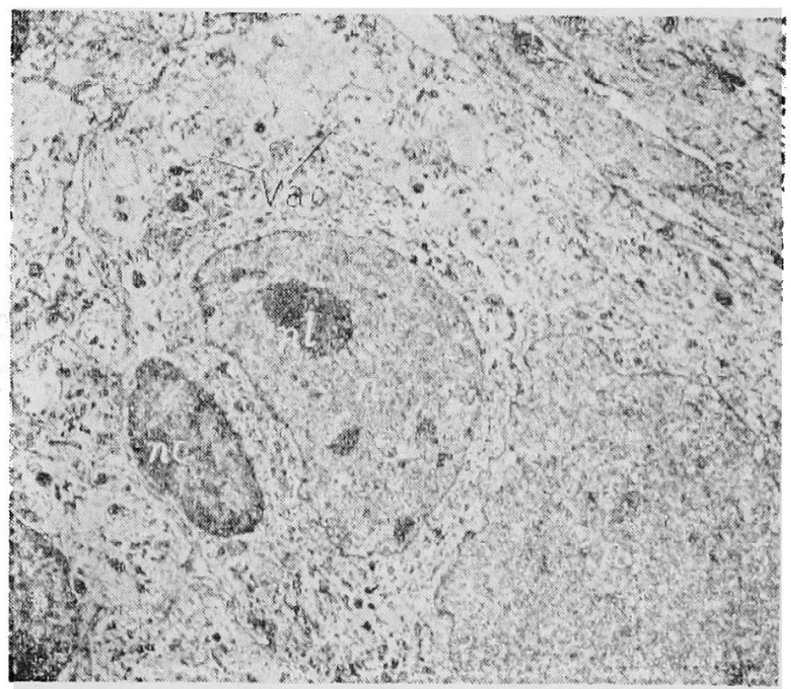


图 25

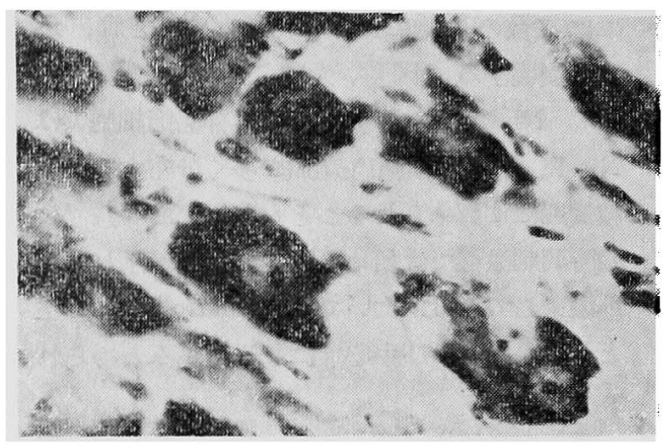

\section{図 26}

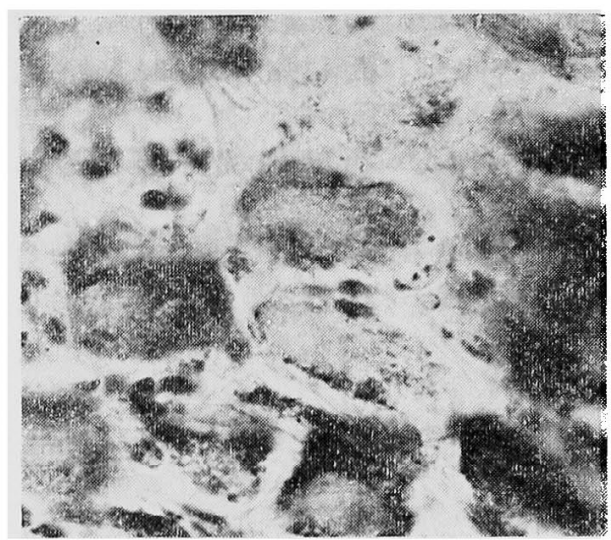

\section{図 27}

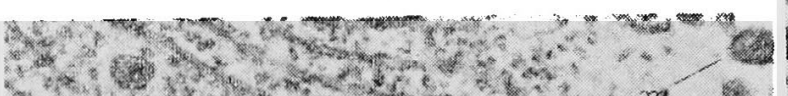

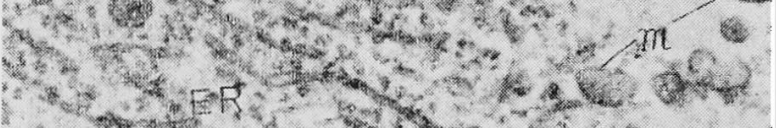

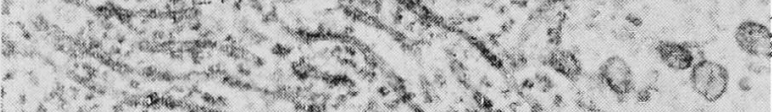

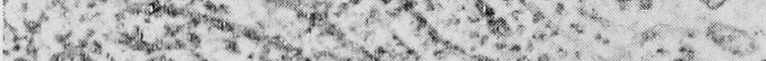

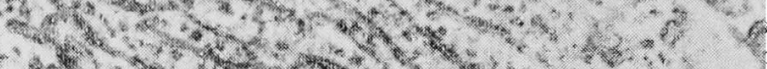

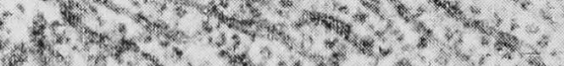

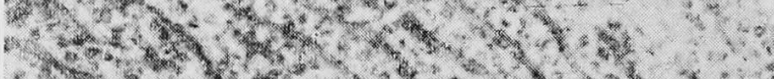

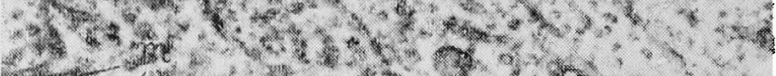

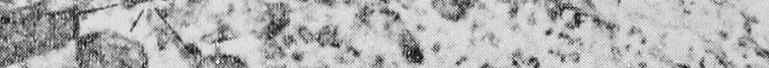

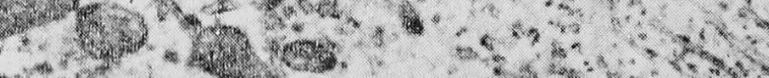

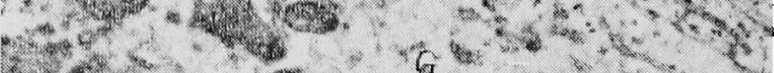

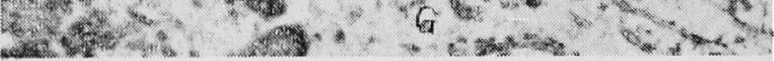

\section{图 28}

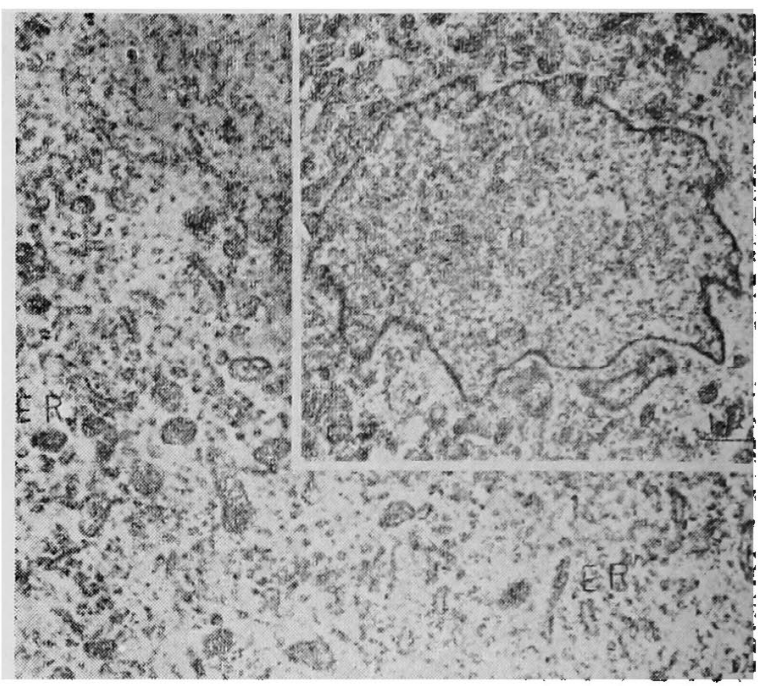

图 29

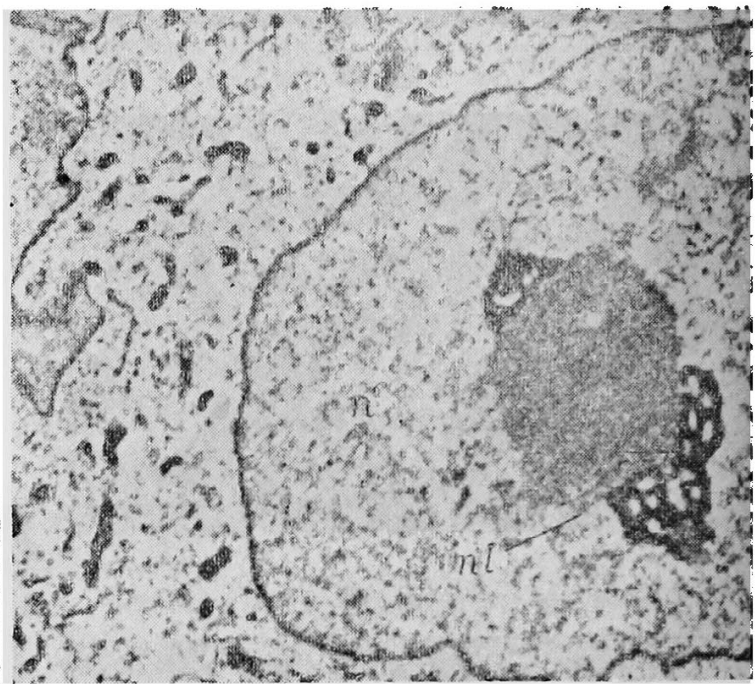

图 30

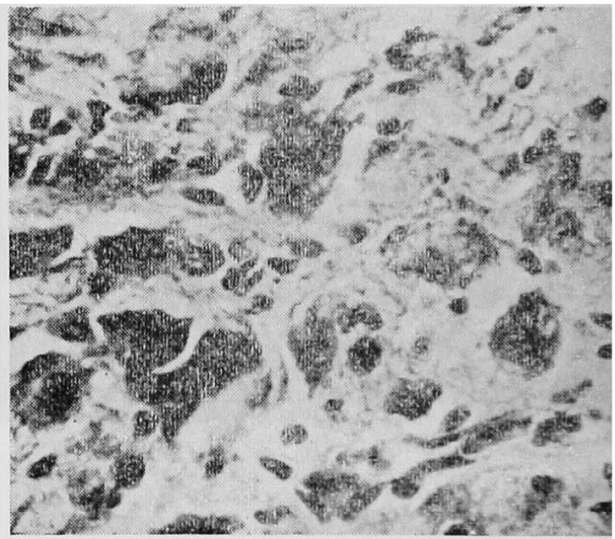


以上の事柿から，自律神経の未梢に加えられた刺激が 中枢に伝えられる経路の一つとし, 上頸部交感神経節が 重要な役割を演ずるものと考光られる. 即ら自律神経が 比較的豊富に分布している口蓋に刺激が加えられると刺 激の一部が上頸部交感神経節を介して全身の自律神経系 に伝達されるのである。この事は同時に観察した腹部交 感神経節にもほぼ同様の変化が認められた事からもその 裏付けがなされたものと云える。

\section{口蓋剌激時における Microcirculation の変動}

次にラッテの口蓋に刺激を加光乍ら腸間膜に扎ける小

図 31 Microcirculation

a

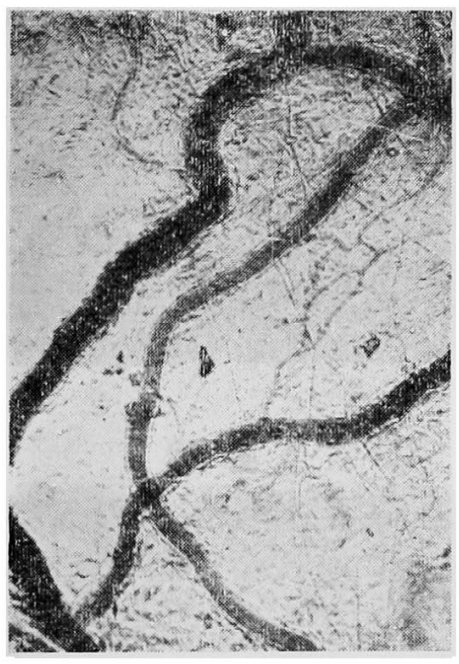

b

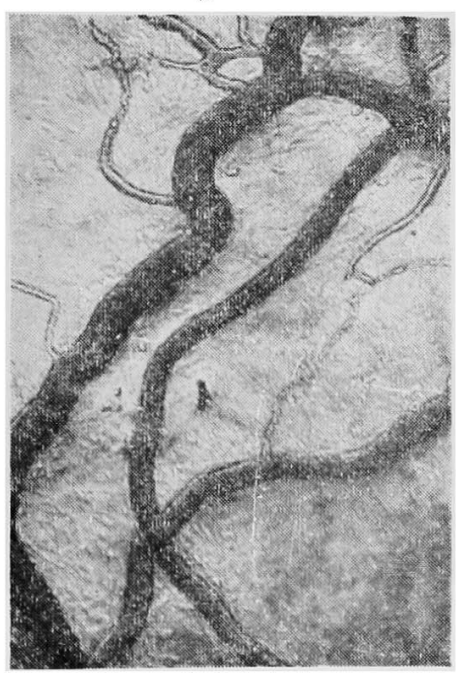

血管の血流変化を钼察 ${ }^{18)}$ してみた．正常時（図 31，a） に比較してクロトン油や電気刺激を加えた場合には，始 めに小血管の収縮を起し，それから拡張がみられ，血流 は緩徐となり，停止又は逆流するという状態が認められ る(図 31, b).

刺激の強い時には血流は全く停止寸るが，軽度の時に は，変化は可逆性で次第に正常に戻るのが認められた。

この変化を抑制するために，予めクロールプロマジンを 注射しておくと，血流の変化は全くみられなからた ${ }^{19) . ~}$

\section{口蓋の剌激時における諸臓器及び腸間膜の血管系の細} 胞学的, 電子顕微鏡的所見

斯くの如く，口蓋に加えられた過剩刺激は自律神経系 を介して，始めに血管系に最も重要な変化を起すことが 明らかにされたが，今日 倘，その透過性等の 重要な問 題があるにも拘らず，ラッテやモルモットの血管に関す る詳細な形態学的研究は正常及び実験上の变化をも含め て全く報告がなされていない

私達は口蓋刺激時のモルモットの諸臟器, 即ち肝, 膵, 腎, 脾, 肺及び腸間膜のほぼー・定の太さを有つ細い 動脈の内皮細胞について観察した. その結果其処に空胞 化があるのを発見した（図 32）は肝小葉間動脈でこの 内皮細胞には著明な空胞化が認められる．脾の中心動脈 (図 33), 腸間膜動脈 (図 34) でも同様に内皮細胞化が 明らかである.一方, 太い動脈, 極めて細い動脈, 毛細血 管, 類洞及び青棦脈の内皮細胞にはこのような空泡化は認

図 32

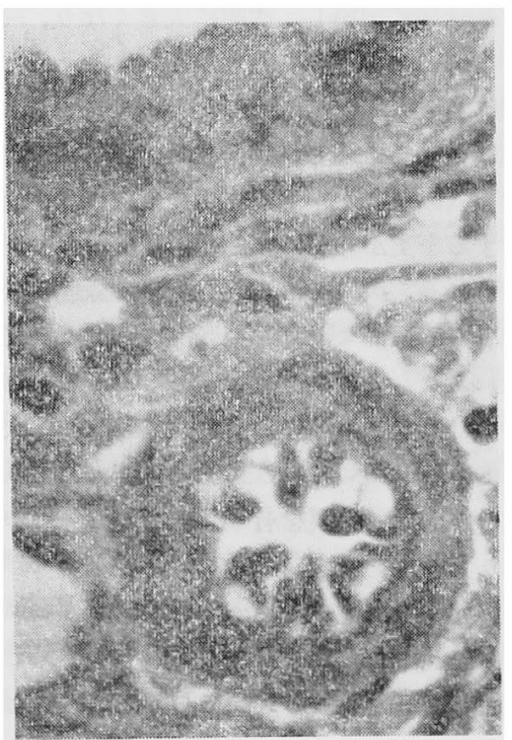


图 33

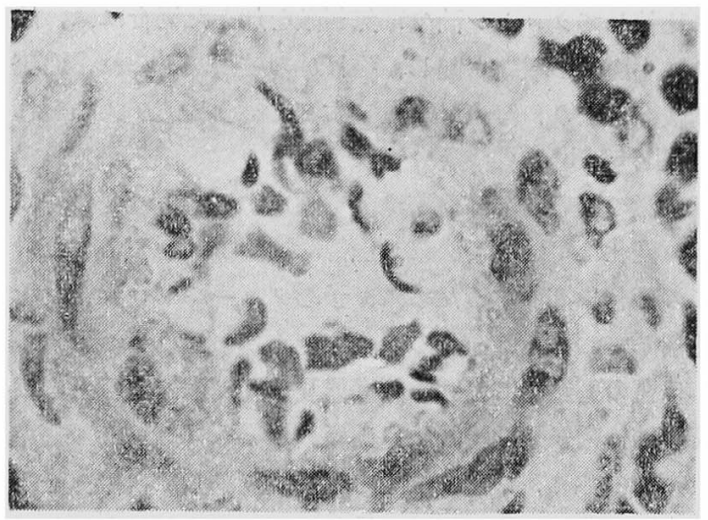

図 34

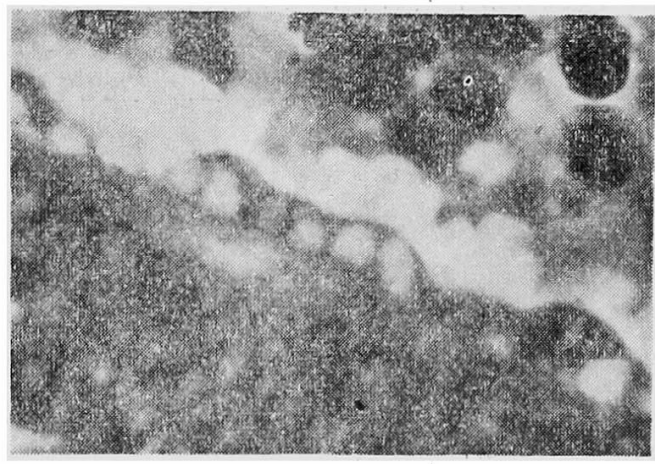

められない，この空胞形成はいかに形成されるか, 又形 成された空胞はその後いかなる連命を辿るかは重要な問 題である. 始めに種々の大きさと数の空胞か゚内皮細胞の 主として基底部に出現し, 次第に大きくなり, 一方互に 融合する事によつてもその大きさを增す，そして遂には 内皮細胞は空胞によつて充満され balloon 状になり, 核は空胞によつて正迫され扁平化し，内皮細胞は血管腔 に突隆する (図 33). 斯かる過程を経て内皮細胞の空胞 化が進行する事実からこの空胞化現象はかなり動的なも のと思考される. 次にこの空胞を電子顕微鏡で観察する と, 主として核側部より細胞基底部にかけて後述の小胞 (Vesicle) よりも大きい空胞を認める.この空胞は光顕 的に認められる小と中等大の空胞 (電顕的には大空胞) に相当している（図35），これを更に搪大してみると空 胞は 2 衩の平滑な限界膜を有し，主として 2 個の空胞の 融合により大きさを增す（図 37).

その他, 光学顕微鏡では見党ない小胞 (Vesicle) が

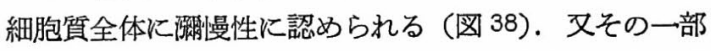
は血管腔面の細胞膜に接し，開口して血液内容を取り込
図 35

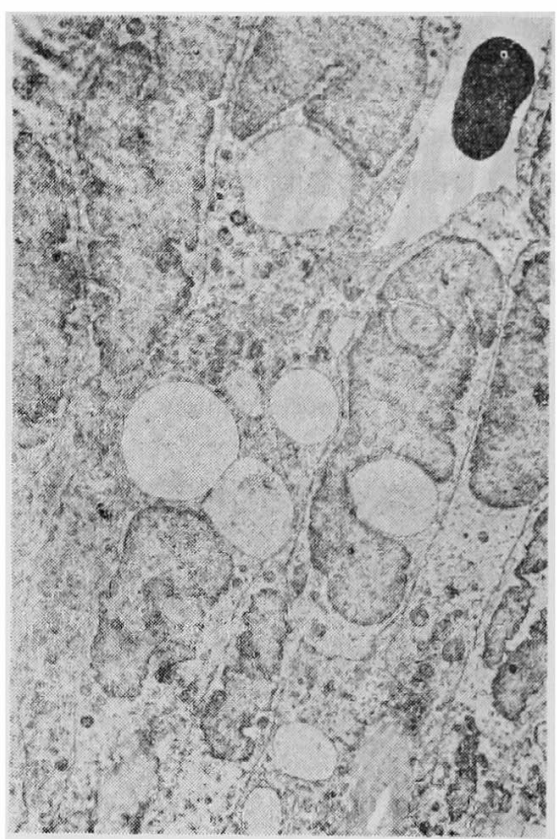

図 36

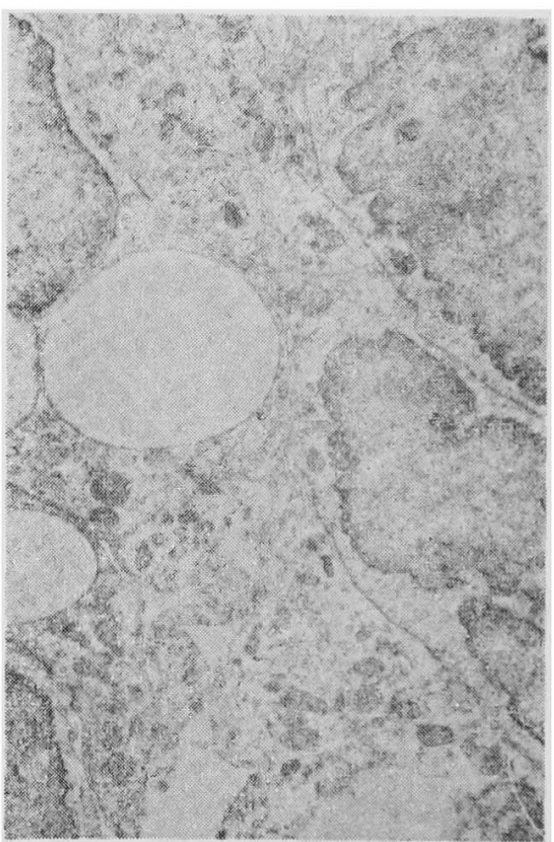


図 39

図 37

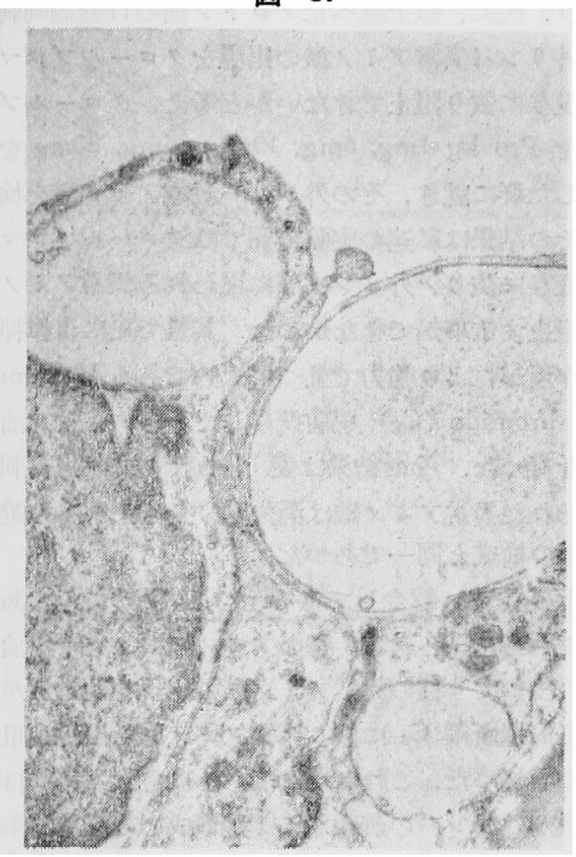

図 38

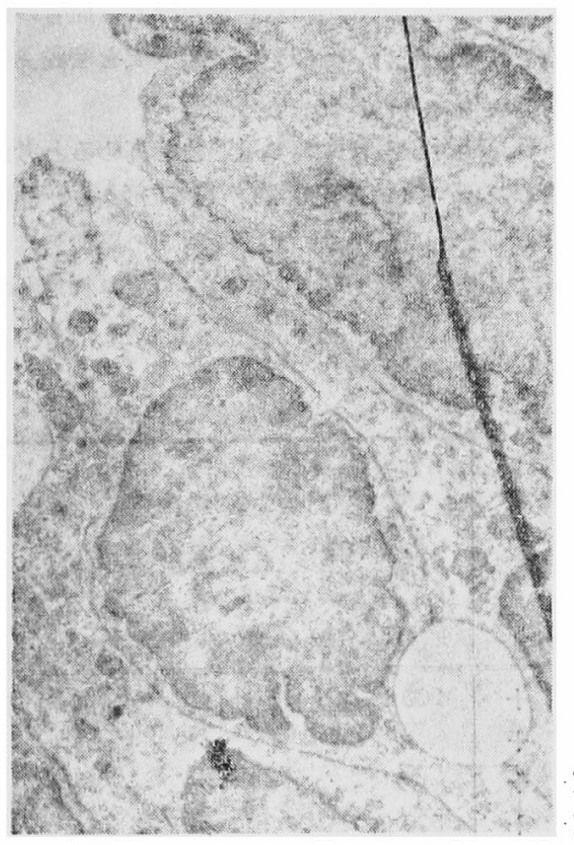

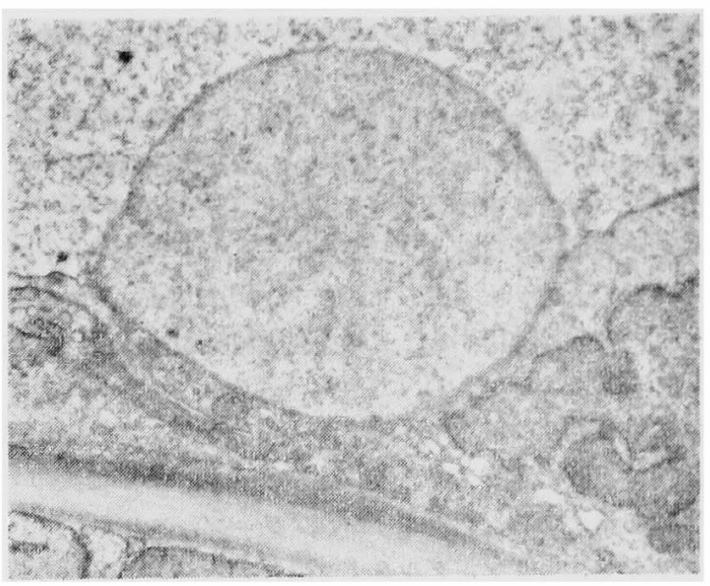

む所謂 Pinocytotic Vesicle の像を呈する.この小胞 が数個融合して，小管状，小麗状と成つて大きさを增 し, その後, 大空胞間の融合が行なわれるのである.

形成された空胞は次の 2 通りの径路で細胞外へ排出さ れる. 第 1 は空胞が間隐へ向つて進み，2枚の限界膜の らち外膜を失い内膜のみとなつて 細胞間隙に落ち込み （図38），細胞間吵を通つて血管腔へ移行する（図 39）.

又この図より細胞の自由表面から空胞が排出されること も考元られる. 第 2 は小数例ではあるが単一膜 (内膜) となつて内皮細胞の基底部にある内弾性板の断㤠部を通 り動脈壁内へ脱出して行くものもある.このようにして 空胞の大部分は血管腔に，一部は血管周囲に排出され る.

空胞内容は屡々電子密度のやや高い小胞体が認めら れ, 所謂 Multivesicular body の像示す 又光学顕 微鏡写真で明らかな如く空胞内容はオスミュウム酸で黒 化せず，種々の染色法にも染らず，PAS 反応陰性の液 状物質である. 過剩刺激時に充血, 出血等の所見以外 に, 全身の比較的細い動脈に扔いて空胞化が認められ, 主として内皮細胞の側面から細胞問吵を経て血管腔へ， 時には自由表面から直接に血管腔へ，一部は基底面から 動脈壁内へ移行寸る事が明らかになつた. 又正常時に拉 いても空胞化が認められるが，これは過剩刺激時に比較 して遥かに軽度であつた。

\section{口蓋刺激が内耳に及ほす影響}

以上は咽頭又は口蓋の過剩刺激方”主として内臓諸臟器 に及ぼす影響であつたが，更に方向を変えて内耳に及ぼ 寸影響を調へてて見ると, 同様の過剩刺激を加えた時の外 
リンパ液には刺激老川えなかつた時に見られる7種類の 遊離了ミノ酸の外に 4 種の異常了ミノ酸の出現が浔めら 机る。

即ち，モルモットの正円筞を露出し，此処から直径的 $0.1 \mathrm{~mm}$ の毛練管ピペットを朋いて双眼契体影微鏡下に 外リンパ液を毛細管現象を利用して採取する34) 35) 36).

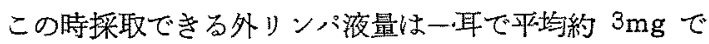
あるので, 外リンパ液， 5 頭，10耳分即ち約 $30 \mathrm{mg}$ を 一、回の実験に使月する。これを東洋源紙製 No. 51 の濾 紙の一端にスポツトし，二次元ペーパークロマトグラフ 法に依り外リンパ液の游離つミ，酸を測定した。そ結 果リンパ液の游離アミノ酸は殆んど全例括いて次の7 種である。即占，グルタミン，アラニン，スレオニン， グリシン，セリン、グルタミン酸，アスパラギン酸であ る. 表8の如く十は明暸に，土は痕跡的涩認められたも の，一は肉眼的に認められなかつたものである.

次に1/200及び 1/500に稀釈したクロトン油をモルモ ットの両側軟口蓋に各々 $0.1 \mathrm{cc}$ ずつ注射して 1 時間後に 同桹の方法で外リンパの遊離アミノ酸を測定した．その 結果は表 9 亿示寸如く前述の正常時に見られる 7 種の遊 離アミノ酸の他に, システイン酸, アルギニン，ヒスチ ジン及びリジンの 4 種の遮崔アミ，酸の出現が認められ た、又この表に見られるょらに，1/200 及び1/500 稀釈 クロトン油を用いた場合，雨者の閂には全く差基を認め 得なからた。

私逵は此の変化がクロトン油艺の物の特殊性に由るも のであるか，あるいは軟口蓋と云う場所的特巽性に因る ものであるかる知るため，対照としてモルモットの腹部

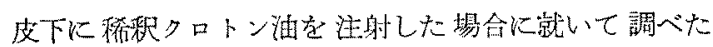
処，1/200稀勫でも 1/5 稀橎クロトン油のいずれに就い ても異常つミノ酸の出現を全く認㧹なかつた事から，
この変化は軟口蓋の局所的要因に因るものと考えてよい と思う。次に, 以上述べたクロトン油の口蓋過剩刺激に 因る外りンパ䔬常了ミノ酸の出現をクロールプロマシン の前投与に低り阻止できないかと考光，クロールブロマ シンをPro $\mathrm{kg} 1 \mathrm{mg}, 5 \mathrm{mg}, 10 \mathrm{mg}, 15 \mathrm{mg}$, 30mg を夫 投与した群に就き，ての外リンパ遊離つミ，酸を检索し た、その結果は私澾の実験範囲ではクロールプロマシン の前投与に低り，外リンバ液に現われる異常つミノ酸を 全く阻止する事ができなかつた，其処で更に自律神経節 遮断作用が，より強力で目つ選択的である Hexamethonium bromide $\left(\mathrm{C}_{6}\right)$ を前投与してからクロトン油過剩 刺湤を行つた。 その結果は表 10 に示す如く過剩刺激時 に現われた異常アミノ酸は消失し, 全く正常時の遊離つ ミノ酸の潔成と同一であつた.

以上の結果を総合してみると，表 11 の如くである. 即ち正常時に見られる7種のアミノ酸にクロトン油口蓋 刺激に徏つて 4 種の異常了ミノ酸の出現を認めるが，自 律神経節遮断削 $\mathrm{C}_{6}$ に依り異常つミノ酸の出現を阻止で きるのを知つた，これにより明らか炕される事は口真過 剩刺激が外リンパの遊離了ミ，酸構成の变動を招来する 事，及び，その間に自律神経が分在している事である。

内耳血管系の特殊性や自律神経支配佂就いては未だ不 明の点が多いが，口蓋炕発した刺激が反射弓をなして内 耳血管遇動神絽に何等かの変化を及ぼし，血管の透過性 を亢進せしめ，外リンパのアミノ酸構成を变動させたも のと考えられる。

斯かる見地から内耳血管の透過性を高めると考元られ る楽郕であるニコチン酸を投与しての結果を観察した が，口蓋刺激時に钼察されたと同種類の異常つミノ酸が

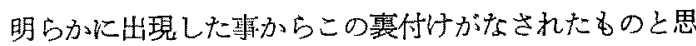
5 .

表 9 口蓋刺激時外リンパ湤遊離つミノ酸

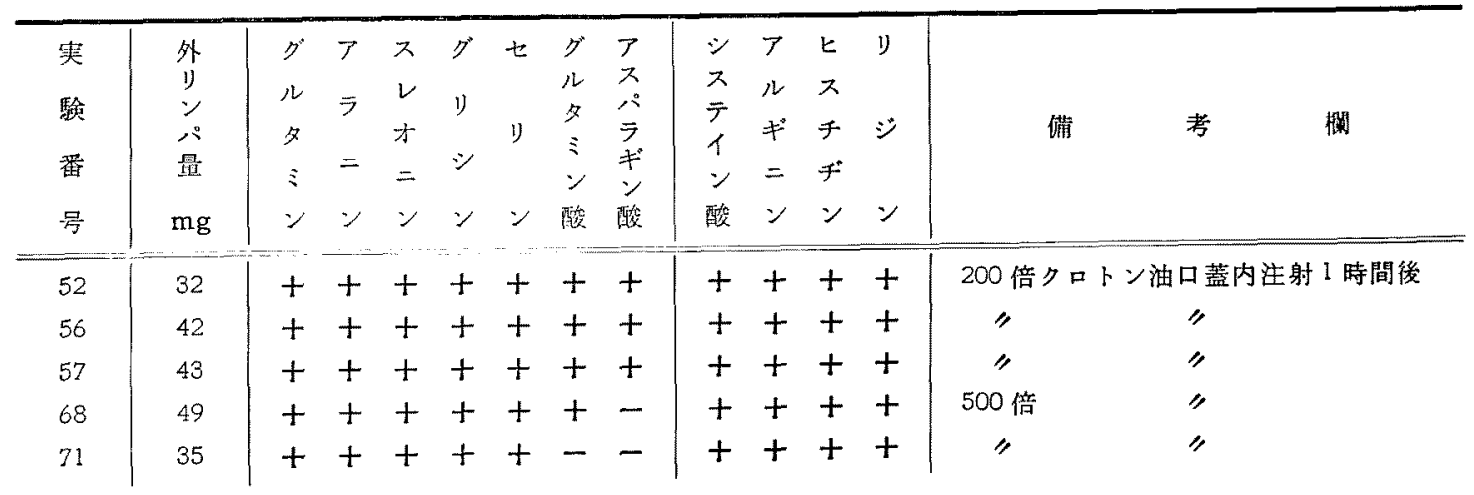


表 $10 \mathrm{C}_{6}$ 前処型時:外リンバ液避踓アミノ酸

\begin{tabular}{|c|c|c|c|c|c|c|c|c|c|c|c|c|c|c|c|c|}
\hline $\begin{array}{l}\text { 烡 } \\
\text { 踰 } \\
\text { 番 } \\
\text { 号 }\end{array}$ & $\begin{array}{l}\text { 外 } \\
\text { ऐ) } \\
Y \\
\therefore \\
\text { mg }\end{array}$ & $\begin{array}{l}ク^{*} \\
ル \\
タ \\
\Sigma \\
ン\end{array}$ & ン & $\begin{array}{l}ス \\
2 \\
x \\
= \\
ン\end{array}$ & シ & $t$ & $\begin{array}{l}\not ゙ \\
ル \\
タ \\
\vdots \\
\text { ン } \\
\text { 酸 }\end{array}$ & 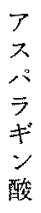 & $\begin{array}{l}\ddot{y} \\
x \\
\bar{テ} \\
1 \\
\text { ソ } \\
\text { 酸 }\end{array}$ & $\begin{array}{l}\text { フ } \\
ル \\
キ ゙ \\
= \\
\text { ン }\end{array}$ & $\begin{array}{l}\text { ヒ } \\
x \\
f \\
f^{\prime} \\
\text { ソ }\end{array}$ & $\begin{array}{l}\ddot{y} \\
\text { ン }\end{array}$ & $\mathrm{C}_{6}$ & C & $\begin{array}{l}\text { 投 } \\
\text { 与 } \\
\text { 方 } \\
\text { 法 }\end{array}$ & 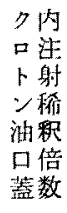 \\
\hline 74 & 30 & $t$ & + & + & + & + & + & - & - & - & - & - & 60 & 4 & 分副投与 & 500 \\
\hline 75 & 45 & + & $t$ & - & + & + & $t$ & + & - & \pm & \pm & \pm & 30 & 3 & " & " \\
\hline 76 & 59 & + & + & + & + & + & + & + & - & - & - & - & 60 & 4 & " & $"$ \\
\hline 77 & 39 & + & + & + & + & + & + & + & - & \pm & \pm & \pm & 30 & 3 & $"$ & $"$ \\
\hline 78 & 38 & + & + & + & + & + & + & + & \pm & 土 & \pm & \pm & 60 & 4 & " & 200 \\
\hline 79 & 49 & $t$ & + & \pm & + & + & \pm & - & - & \pm & \pm & \pm & 30 & 3 & " & " \\
\hline
\end{tabular}

表 11

\begin{tabular}{|c|c|c|c|c|}
\hline & \multirow[b]{2}{*}{ 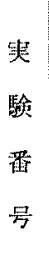 } & \multirow[b]{2}{*}{$\begin{array}{l}\text { 外 } \\
\text { リ } \\
ン \\
\therefore \\
\text { 量 } \\
\mathrm{mg}\end{array}$} & JE 常 アミ，酸 & 舆常アミノ陵 \\
\hline & & & 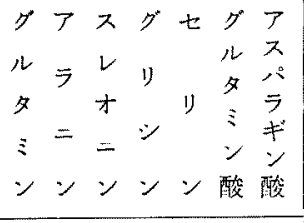 & 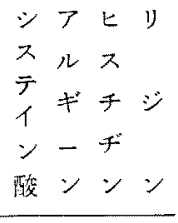 \\
\hline & 19 & 33 & $t+t+t+-$ & ---- \\
\hline 正 & 20 & 38 & $t+t-t+t$ & ---- \\
\hline & 21 & 35 & $t+t+t+t$ & ---- \\
\hline & 22 & 31 & $t+t+t+t$ & ---- \\
\hline 常 & 30 & 33 & $t+t+t+t$ & \pm \pm \pm \pm \\
\hline & 32 & 35 & $t+t+t+t$ & ---- \\
\hline & 33 & 39 & $t+t+t+t$ & \pm \pm \pm \pm \\
\hline & 37 & 33 & $t+t+t+t$ & - \pm \pm \pm \\
\hline 衔 & 38 & 24 & $t+t+t+t$ & --- \\
\hline & 41 & 42 & $t+t+t-t$ & ---- \\
\hline 口 & 52 & 32 & $t+t+t+t$ & $t+t+$ \\
\hline 㦈 & 56 & 42 & $t+t+t+t$ & $+t+t$ \\
\hline 刺 & 57 & 43 & $t+t+t+t$ & $+t+t$ \\
\hline 潡 & 68 & 35 & $+t+t+t-$ & $+t+t$ \\
\hline 非 & 71 & 49 & $t+t+t--$ & $t+t+$ \\
\hline & 74 & 30 & $t+t+t+-$ & ---- \\
\hline$U_{6}$ & 75 & 45 & $t+-t+t+$ & - \pm \pm \pm \\
\hline 投 & 76 & 59 & $t+t+t+t$ & ---- \\
\hline 5 & 77 & 39 & $t+t+t+t$ & - \pm \pm \pm \\
\hline 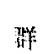 & 78 & 38 & $t+t+t+t$ & \pm \pm \pm \pm \\
\hline & 79 & 49 & $+t \pm t+ \pm-$ & - \pm \pm \pm \\
\hline
\end{tabular}

仙，先に述べた如く，クロールプロマジンに依つては この翼常アミ，酸の出現を阻处する事ができなかつたの は，その自律神経節遥断作用がやや留いためか，星の多

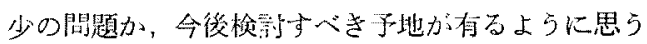

\section{手術時の侵䌦が過剩剌激になる事について}

それでは臨床的に手術と云ら侵繁が人体に如何なる変 化を与えるかと云ら事を，主として扁桃手術の時に㜣い て調ベてみた。

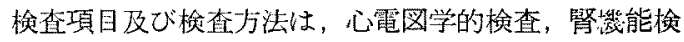
查，血液検雷，脳波の4項目に溦いて行つた。

1. 心電図学的檢查は日本光電淛の直記式心電計を用 いて術前，術後を通じて計 10 回に亘りいずれも仰卧位 にて撮影した。手術開始後の各時期における心電图上の 主な変化は ST 下降，T平低及び逆転，Pの变化等で あり，最多く且つ明らかな变化を示したのは ST，T

$$
\text { 図40扁摘時のST变化 }
$$

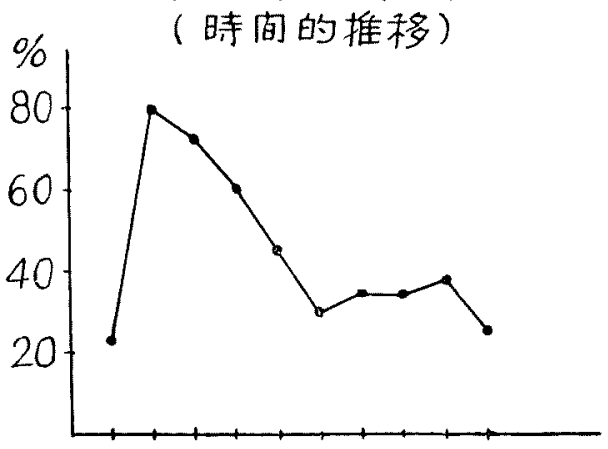

街注街 3011.52137 射道時時時日白日 㓣後後分间间间目目目 
図41扁摘時の丁变化

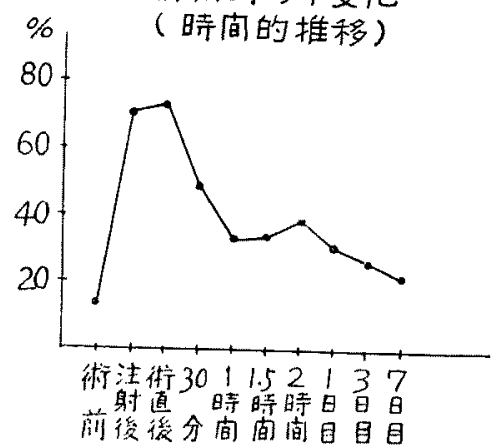

等である、この ST, T変化の㭙間的推移を観察すると

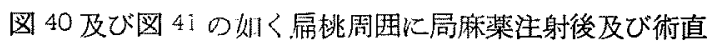
後では $70 \%$ に変化が 現われ，術後 30 分乃至 1 時間では $50 \%$ に減少し，以後は濑洔大半が術前の状態に回復し7 日目に術前之略々同し数值を示している。

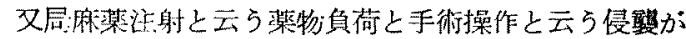
心に及ばす影微は同一の刺激となり得るかと云うことを

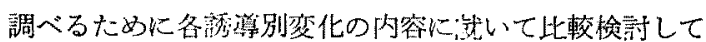
見ると図 42，図 43 の如く肢誘尊でも 胸部誘道でも局麻 薬注射も手術直後も同一の变化内容を示し有意の差は認 められない 即ら薬物負荷と手術的の器械的侵㢺が心に 及注す变化は略々同一と考えて良いであ万ら。これから 考之ても扁桃手術時の局所麻醉薬の注射はかなり強い刺 激々なるもので，手術時に起るショックの発生が術前所 直としての局麻薬の注射直後に最も多いという統計を寒

图 42 ST の誘導別変化（扇桃周围注射後と 術直後との比校)
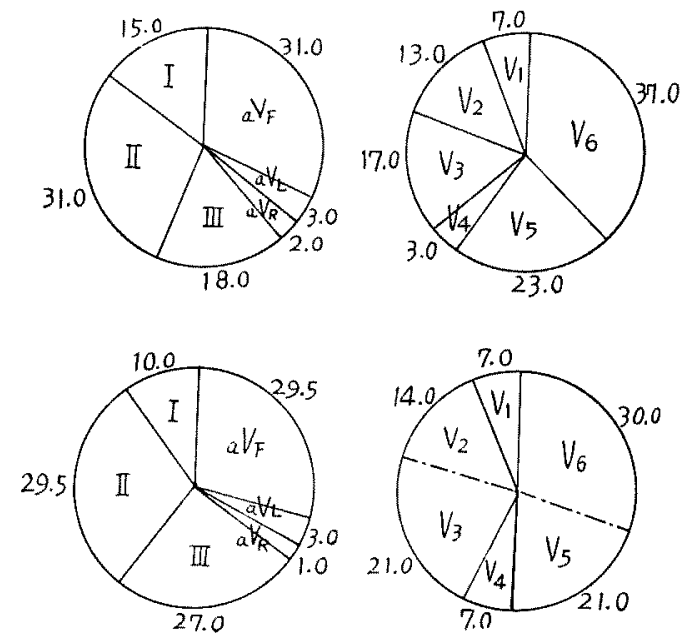

图 43 T波の誘道別变化(扁桃周囲注射後と 術直後との比較)

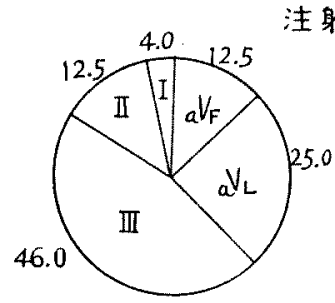

注射後
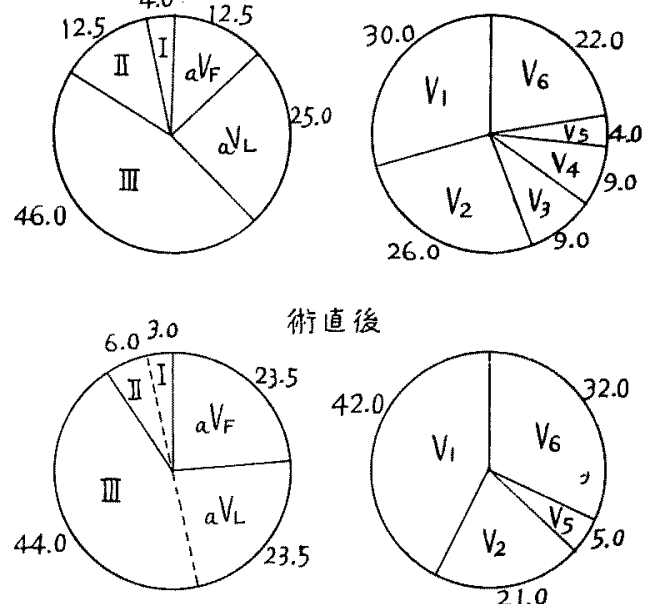

術直後

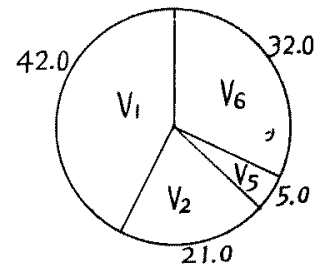

付けるものである。

其処で手術时に使用する桨郕の種類に因る影策を考 え，0.5\% \%シロカインと同じ潧度のノボカインを使用 してみたが，両者共全く同様に ST，Tの変化を認めた ので，更に扁桃周丑に生理食塩水を 注射した時と $0.5 \%$ キンロカイン注射後との心電図を同一应例に就いて比較 して見たが，殆んど差がなく，生食水の注射でも全く同 一の心電図学的心筋障害が認められた。この事から手術 時の口蓋扁桃附近の自律神経過剩刺激は薬物に依る化学

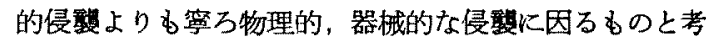
えられる. 又前述の如くモルヨドールを屚桃周囲に注射 したたけでも全く同様の心電図学的变化を生ずる事もこ れを襄付けるるのと云える。

扱，以上述へた ST, T の変化は如何なる理由に基つ くものであろらか.

私が観察したこれら，ST，Tの变化は詳細に分析する

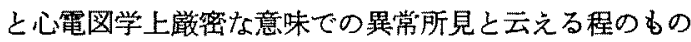
ではない 42）43)，窖ろ正常範囲内の変化であつて，而も その変化は一過性であるため心䐵澡質的な障碍が起つ たとは考觉られない，

このように僅かな心電図学上心筋障害を来主様な因子は 表 12 に示寸如き数項目に尽きると思われる。

第1に外来アドレナリンに的る影䆄が考えられるが， これに就いてはアドレナリンを加えない，0.5\%キシロ カインと同濃度のノボカインを用いてもいずれも全例比 同棣の変化を認めた．又表 13 の如く扁桃周围に 注射し 
表 12 埾微なST 変化をきたす諸因子

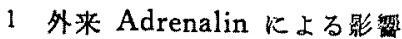

2 Electrical Heart Position の変化による 影嘅

3 Tachycardia による影響

4 Hypo-Kalemia Kよる影犁

5 Anxiety による影缊

6 Focal Infection による影留

7 Reversible Coronary Insufficiency (自律 神程を介して生したもの）の影響

表 13 フドレナリン上膊注射と局麻剂 扁桃周囲注射との比較

\begin{tabular}{|c|c|c|c|c|c|c|}
\hline 例 & 令 & 別 & $\begin{array}{l}\text { 上朠注射 } \\
\left(\begin{array}{ll}\text { 全 } & \text { 例 } \\
0.3 \mathrm{mg}\end{array}\right)\end{array}$ & 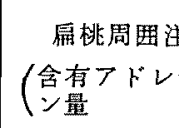 & $\left.\begin{array}{l}\text { 射 } \\
\text { リ } \\
\mathrm{mg}\end{array}\right)$ & $\begin{array}{l}\text { 街 前 } \\
\text { 心䉓图 } \\
\text { 異 常 } \\
\text { 所 見 }\end{array}$ \\
\hline 1 & 12 & q & 変化なし & ST. T. & & な \\
\hline 2 & 16 & " & " & " & 0.13 & " \\
\hline 3 & 19 & 0 & " & " & 0.15 & " \\
\hline 4 & 20 & q & $"$ & S T i & 0.15 & " \\
\hline 5 & 25 & $"$ & $"$ & $T i$ & 0.13 & $"$ \\
\hline 6 & 27 & $"$ & " & $\mathrm{ST} \downarrow$ & 0.15 & " \\
\hline 7 & 30 & " & " & ST. T. i & 0.15 & $"$ \\
\hline 8 & 11 & $"$ & $\mathrm{~T} \uparrow$ & $T i$ & 0.10 & " \\
\hline 9 & 26 & $"$ & $\mathrm{ST} \uparrow$ & ST. T. i & 0.15 & $"$ \\
\hline 10 & 17 & $\delta$ & $S T \downarrow T:$ & " & 0.20 & M. D \\
\hline 11 & 18 & 우 & $\mathrm{T} !$ & S T. T. & & L. V \\
\hline
\end{tabular}

た $0.5 \%$ キシロカインに附加されたアドレナリンの量は $0.15 \mathrm{mg}$ 以下である。今この倍量の $0.3 \mathrm{mg}$ 老上膊皮下 に注射し 15 分後に心電图を撮影したが，11 例中７例が 不変であつた。この事から私達が使用した $0.15 \mathrm{mg}$ 程度 の外来アドレナリンの負荷による心電図への影響は44)

15) 46) それ程大きいむのとは考えられない。

第20心缄䉓気軸に旺る影響については常に同一,体位 で心電図を撮影した事と QRS.Axis 及び移行帯が90\% 以上不变である事から之を否定し得る。

第3の頻脈に因る影制は每分 120 以上に增加した例は 15\%しかない，一般に 120 以下ではST, Tに左程強い 影留を与えるとは考えられないので，この影繁子除外し て庭いと思ら。

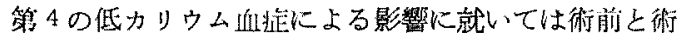
直後の任清カリウムを比較したとこる，全例が正常籍囲

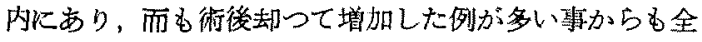

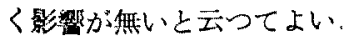

图 44 届摘全麻例の心電龱上亲化の時間的推移 (フトレナリン添加のキシロカイン)

\begin{tabular}{|c|c|c|c|c|c|c|c|c|c|c|c|}
\hline & & $\begin{array}{l}\text { 全 } \\
\text { 磨 } \\
\text { 前 } \\
\text { 前 }\end{array}$ & $\begin{array}{l}\text { 注 } \\
\text { 射 } \\
\text { 後 }\end{array}$ & $\begin{array}{l}\text { 衡 } \\
\text { 证 } \\
\text { 特 }\end{array}$ & 分 & $\begin{array}{c}1 \\
\text { 特 }\end{array}$ & 1.5 & $\begin{array}{c}2 \\
\text { 時 } \\
\text { 間 }\end{array}$ & 日 & $\begin{array}{l}3 \\
\text { 日 }\end{array}$ & 日 \\
\hline S T & $\begin{array}{l}\text { A } \\
B \\
C\end{array}$ & $\begin{array}{l}- \\
- \\
-\end{array}$ & $\begin{array}{l}- \\
-\end{array}$ & $\begin{array}{c}- \\
\vdots \\
\vdots\end{array}$ & $\begin{array}{c}- \\
\vdots \\
-\end{array}$ & $\begin{array}{l}i \\
-\end{array}$ & - & $\begin{array}{c}i \\
- \\
-\end{array}$ & $\begin{array}{c}\vdots \\
- \\
-\end{array}$ & - & $\begin{array}{l}- \\
- \\
\hat{n}\end{array}$ \\
\hline$T$ & $\begin{array}{l}\mathrm{A} \\
\mathrm{B} \\
\mathrm{C}\end{array}$ & $\begin{array}{l}- \\
- \\
-\end{array}$ & - & $\begin{array}{l}- \\
- \\
-\end{array}$ & $\hat{\imath}$ & - & $\begin{array}{l}t \\
\vdots\end{array}$ & $\hat{\imath}$ & $\begin{array}{l}- \\
- \\
-\end{array}$ & $\begin{array}{l}- \\
- \\
-\end{array}$ & $\begin{array}{l}- \\
-\end{array}$ \\
\hline
\end{tabular}

第 5 の術前の精神的不安，手術に対する情緒的祭倨が

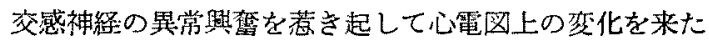
寸事に就いては術前安蒴洔と術直前に心電图を記録して 此較検討して見たが，变化を認めたものは10例中臟か

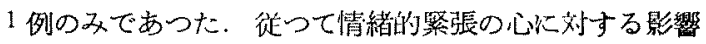
は堵いものと考えられる。

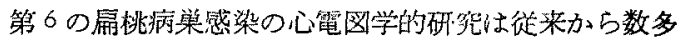
く報告され枚誉にいとまがない，併し病栄感舞の心電图 上異常所見 44) 45) 48４7）48４9，55) の成立機序に関しては 不明の点が多く未柾定钻がない，乙れ故，私は斯かる心

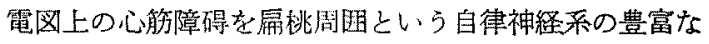
部位の剌激により自律神縚系を介して生した冠不全の一 つの型を見ているのでは然いかと思はれる。即ち，冠不 全に因る主として心内膜下の可逆的な心䂏障碍の現われ ではないであ万らが5)，又家乘の口盖扁桃部位のクロト

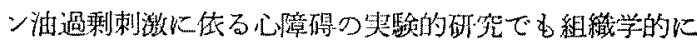
楼血，充血の著明な循㱬障碍つみでするという報告から も，これ等のST，Tの变化が心電図上に一過性の心筋 障碍として現われるといら哥の裹付斿となるであるう。

扁桃病策感染の翼常心電图として取り上げられてきた

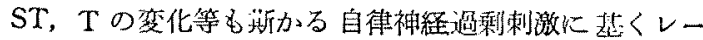
リ一氏現象との関連加ら检索を加える其子，その成因棬 序の解明に残された今後の課題であると思ら。

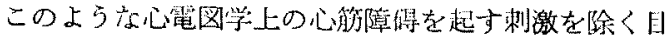
的でクロールプロマシンに依るカタテル楽醉を試みたが 期待するよらな絬果は得られなかつた．侀しエーテルに

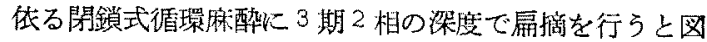
45 の如く ST, T の绞化が鼠桃夙国注射传と術值後には 珰好られず，30 分以上を程過して㳭度が线くなると始 めて変化が止ずる。この歌は深度が深い時には自律神経 系が遮断され，手術時の過剩刺激を抑制し得る李を示暧 
图 45 扁摘時安静時脳波

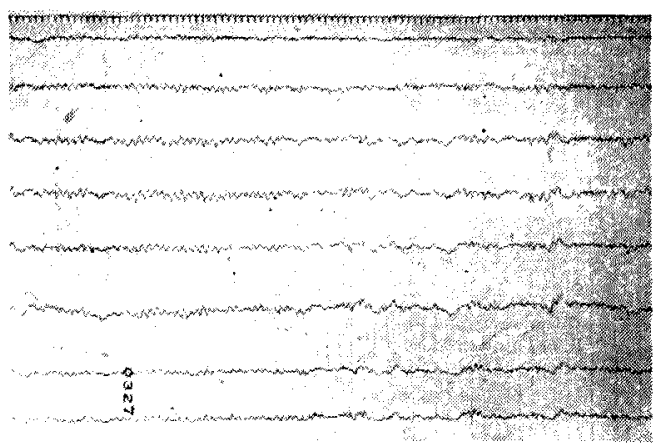

表 14 扁摘後，尿望白及び尿赤血球の消長

\begin{tabular}{|c|c|c|c|c|c|}
\hline 期 & 術 & 1 病 日 & 3 & 病 & 日 \\
\hline 㲾垔白 & $\begin{array}{c}(-) 50 \text { 例 } \\
(100 \%)\end{array}$ & $\begin{array}{l}( \pm) 15 \text { 例 } \\
(-) 35 \text { 例 }\end{array}$ & $\begin{array}{l}(+) \\
(-)\end{array}$ & $\begin{array}{l}12 \text { 例 } \\
38 \text { 例 }\end{array}$ & $\begin{array}{l}(24 \%) \\
(76 \%)\end{array}$ \\
\hline $\begin{array}{l}\text { 泳标血赇 } \\
\text { (沈㳂中) }\end{array}$ & $\begin{array}{c}(-) 50 \text { 例 } \\
(100 \%)\end{array}$ & $\begin{array}{l}\text { (+) } 14 \text { 例 } \\
(-) 36 \text { 例 }\end{array}$ & $\begin{array}{l}(+) \\
(-)\end{array}$ & $\begin{array}{r}9 \text { 例 } \\
41 \text { 例 }\end{array}$ & $\begin{array}{l}(18 \%) \\
(82 \%)\end{array}$ \\
\hline
\end{tabular}

していると考えられる，それ故，扁摘時のショック予防 には全身麻酔が最も安全であると云兄る。

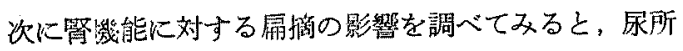
見では表 14 の如く術後，尿蛋白，尿沈渣中の赤血球の 出現率が $30 \%$ 前後であり，術後 1 週間で大部分が消失 する傾向を示している．尿中に硳白や赤血球の出現寸る 原因は疾病に依り種々醅論されているが，この場合は口 蓋:震桃部位の過剩刺激により，自律神程を介して㫧球体 血管还過性の一過性の変化に因るものと考光られる。

即引腎㙨能検查でも術前安静時に比べて術後 2 時間以 内行つた腎血墏流量 (R.P.F.) は殆んど差がなく，夈 球体濾遄值 (G.F.R.) が上算している. 従つて 濾過率 (F.F.) の墙加が認められる. 即らこれは堅系球体の輸 出血管の収緮により濾過王が增大した事を思わせる成綪

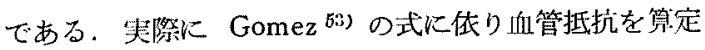
したところ，10 例中 7 例に輸出血管抵抗の増大を認め た、この事は腎の自律神経分布が主に輸出血管に多いと いう文献的考察に 51) 52)一致するところである.

又, 慢性扁桃炎㭧者の腎機能障害娆能的，可逆的 で，屚搁に上りその $80 \%$ 以上が回復するという報告を 璋付けるものである54)

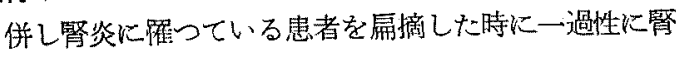
機能障慧が起つたり，筩炎の雭化を見る事があるが，こ

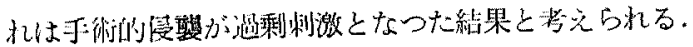

\section{図 46 扁桃周囲局所麻醉剂注射後の譄波}

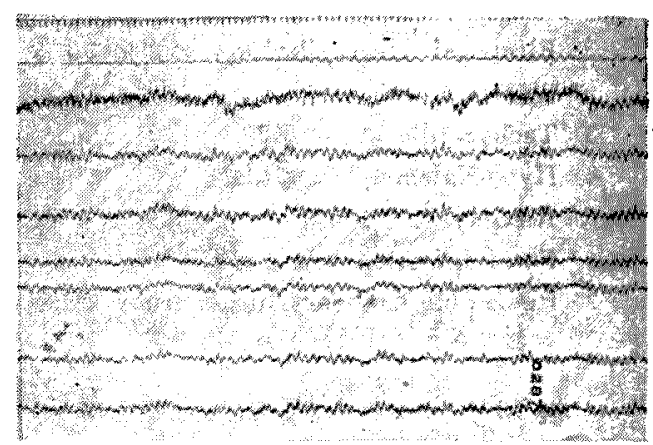

この事からす珡炎患者の扁摘は慎重に行われねばならな w.

最後に扁摘の脳波に及ぼす影響を日本光電製8 素子腅 波計を用いて観察した。

誘導部位は 10 個所の甪側単㥛誘導で測定した．扁侬 周囲麻酔薬注射後の脳波には図 45,46に見られるように 振湢減少，振斯数增大，極波に近い波形が見られる。 とより脳波は多種多様の因子に依つて影製され，これが 直ちに自律神経起原のものとは断定できないが，口蓋扁 桃周囲に楽物を 注射する牙により確かに，何等かのイ ンパルスが大脳皮質下部に伝つている事を意味してい ‡.

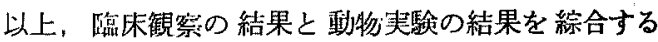
と、口蓋普桃部位の過剩刺激は自律神経系を介して一旦 脑中枢に羊し，それから下降して遠隔葴器の血管運動神 慈:来端䚮に至り，主として血管系の病変を起すものがす るよらに思われる。

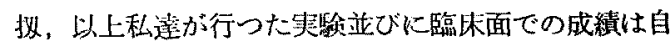
律神船つ発这した咽頭や口蓋を刺激部位として撰んだ が，一方々の大部分が知觉神経から满成されている下眼

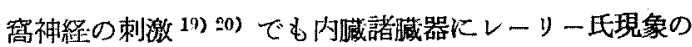
時に見られると同一の病变が認められた。㕛片側の気管 支を刺激すると刘側の気管支に出血等の血管系の変化を 起すのが認められた ${ }^{30)}$.

更に臨床上一側の副単腔など楀の手術を行つた際に， 反対側の眼瞼浮庫や出血21る来たす事がある。これは 動物东験と比較検討の結果からもレーリー氏現象と看做 して良いと考えられる22) 31)。

\section{おわりに}

以上述ベた如く，咽頭や頸部を始めとして，耳累咽堠

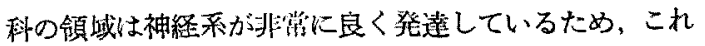


等の部位の手術に゙，もとより細菌，細菌错素並びに器械 的，化学的刺激心過剩刺激と成り易く，全身銗臟器及び 諸器管に, 主として自律神絽系を介して血管系の病変， 即らレーリ一氏現象を起すむのと考えられる。そしてそ の急激なるものはショックとなり緩漫なるむのは所謂病

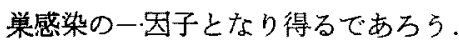

これ等の作用は当然体液及び内分泌采などにも影響を 及活すものであるから事際上の動きは更に複雑なものと なろら、この点に武いて，私達も目下追求中である。

\section{主要硆考文献}

1) Teissier P., Reilly J., Rivallier E., Cambessedes H. et Delalande J.: Ann. de Méd., avril 1930, p. 333. 2) Id. (2e Memoire),: Ann. de Méd, déc. 1930, p. $524 . \quad$ 3) Reilly J., Rivallier $E$.,

Compagnon A. et Daplane R: C.R. Soc. de Biol., 5 mai 1934, t. 116, p. $24 . \quad$ 4) H. Laborit (山口他 嘼): Réaction organique â l'Agaession et Choc,

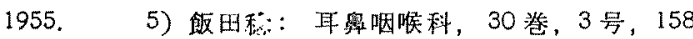

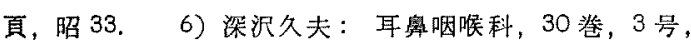
169 頁，昭 33. 7) 鈴木，八十島他：耳䢵咽喉科， 30 巻，3号，153頁，昭 33.8 8) 鉿木安恒他：耳鼻 咽呢科，30巻，10号，774面，昭 33.9）宮部䭷：

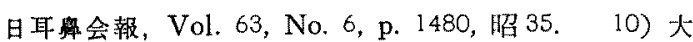
野文朗：日耳壆会報，Vol. 63，No. 1，p. 56，昭 35 。 11）井上寿䊦：日耳率会報，Vol.63, No. 4, p. 995， 炤 35. 12）食井秀夫：日耳䢵会報，Vol. 63，No.

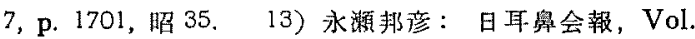
61, No.9, p. 1480, 昭 33. 14) 玉川健二郎：日用奥 会報, Vol. 63, No. 4, p. 978, 昭35. 15) 五十崫第

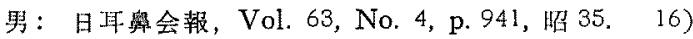
收口正焳：日耳受会報，Vol. 64, No. 2, p. 241, 昭36. 17）目口䇛：日耳奥会報，Vol. 64, No. 2, p. 278, 昭

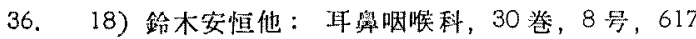

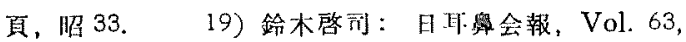

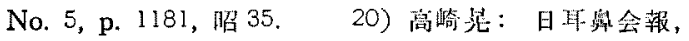
Vol. 63, No. 5, p. 1250, 昭 35. 21) 铪水资恒他：
耳奥咽喉科，30巻，10号，800頁，昭 33.

22) 斎茠

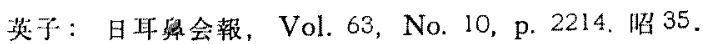
23）鈴木灾恒他：日是会報，Vol. 65, No. 9, p. 1057, 昭37. 24) 松村弘: 未発表. 25) 中山洋: フレルキ゚ー。5巻，2号，75页，1956年。26)器山 勝：未発表. 27）德丸徽：未発表。2 28）杉山 然: 未発表。29）唋木安恒：クロールプロマジン

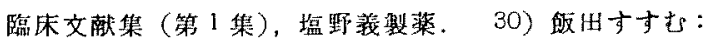

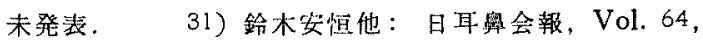
No. 6, p. 1127, 昭 36. 32) Chevance, L.G.: Acta otolog, 49, 509, 1958. 33) Chevance, L.G. et al: Annales a'oto-laryng, 73, 273, 1956.34$)$ Aldred, P. et al: J. physiol, 98, 446, 1940, 35) 松生栄治: 日耳奥会報，Vol. 60, No. 5, p. 502, 昭 32. 36) 伊 藤明和：日耳鼠会報，Vol. 64, No. 5, p. 923, 昭 36 . 37) 坂本，曰井：未発表。38)鉿木安垣化：日耳 覓会報, Vol. 65, No. 9, p. 1057, 昭 37. 39) Steinkopf: Das Elektrocardiogramm. Drsden, 1942, 1947. 40) Lepschkin, E. \& Raab W,: Federation proc.

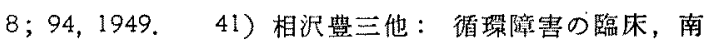
山堂, 昭 33.42) 上田英堆他：臨床心電図学, 南1 堂, 昭 34. 43) Goldman, D: Principles of Clinical Electrographies, 2nd. 1958, 44) 堂野前維泵郷: 日本臨床，15巻，9号，1642 頁，昭 32 . 45) 竹田硅

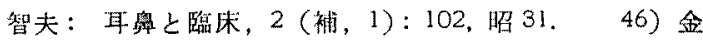

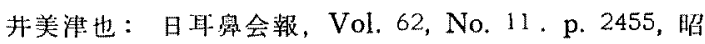
34. 47) 野坂保次: 日耳形学会第 62 回学術講演宿

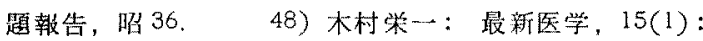

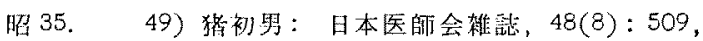

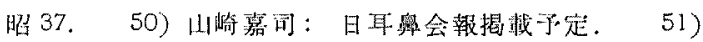
Smith, H.W.: The Kidney, Oxford Univ. Press, 1951. 52) Pfiffer, R.W. et al: Pro Soc. Exp. Biol. Med. 75, 791, 1951. 53) Gemez, D.M.: Fed. proc., 7: 41, 1947. 54) 酒牛鉄郎: 日耳菑会款, Vol. 62, No. 10. p. 15, 昭 34,55) 木村通明：日耳: 会会報，61，(10): 1672, 昭 33 . 